Discussion Paper No. 11-083

\title{
Productivity of ICT and Non-ICT Capital - The Role of Rates of Return and Capital Prices
}

Thomas Niebel and Marianne Saam

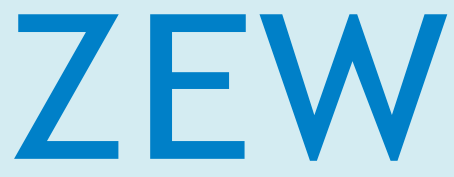

Zentrum für Europäische Wirtschaftsforschung $\mathrm{GmbH}$

Centre for European Economic Research 


\title{
Discussion Paper No. 11-083 \\ Productivity of ICT and Non-ICT Capital - The Role of Rates of Return and Capital Prices
}

\author{
Thomas Niebel and Marianne Saam
}

Download this ZEW Discussion Paper from our ftp server:

http://ftp.zew.de/pub/zew-docs/dp/dp11083.pdf

Die Discussion Papers dienen einer möglichst schnellen Verbreitung von neueren Forschungsarbeiten des ZEW. Die Beiträge liegen in alleiniger Verantwortung der Autoren und stellen nicht notwendigerweise die Meinung des ZEW dar.

Discussion Papers are intended to make results of ZEW research promptly available to other economists in order to encourage discussion and suggestions for revisions. The authors are solely responsible for the contents which do not necessarily represent the opinion of the ZEW. 


\section{Non-Technical Summary}

Decomposing sources of growth in a growth accounting framework relies heavily on price measures as proxies for input productivity. We show how different price measures affect the contribution of investment to growth in labor productivity and determine the share of this contribution that results from improved quality of ICT capital. The price measures we consider are the rate of return to capital and the rate of decline in ICT asset prices. If they represent productivity in an undistorted way, their effects correspond to the effects of marginal productivity of capital and embodied technological progress. The analysis is based on data from the EU KLEMS database for seven countries in the period of $1990-2007$. Our aim is to disentangle the effect of the overall level of the rate of return and the overall decline in ICT prices from the effect of differences in these measures across countries, sectors and time. While it is plausible to consider that the overall level reflects economic and technological conditions, we presume that the differences are at least more prone to measurement error.

Alternatively to the measures from the EU KLEMS database, we introduce a constant real rate of return to capital of $4 \%$ and a rate of decline in ICT asset prices equal to the US average between 1990 and 2007. The sensitivity analysis reveals that most growth accounting results with data from the EU KLEMS database are comparatively robust. Solely for the period from 1995 - 2000 we obtain a substantial decline in capital contributions in both the UK and the US using the constant rate of return to capital. This in turn points to a greater contribution of multi-factor productivity. The decrease in the contribution of non-ICT capital is more pronounced than the decrease in the contribution of ICT capital. As the constant rate of return, alternative ICT deflators somewhat downplay the role investment played relative to growth in multi-factor productivity in the UK and the US during $1995-2000$.

The second main element of our paper is the decomposition of ICT capital contributions into contributions of quantity, quality and the change in the composition of ICT capital. The latter describes variations in the shares of hardware, software and telecommunications equipment in total ICT capital. We show that more than half of the ICT contribution to labor productivity growth results from changes in quality and the composition of capital. Between 2000 and 2007, the contribution of ICT quantity is close to zero in some countries, while replacement of depreciated capital goods leads to a positive contribution of quality. 


\section{Das Wichtigste in Kürze}

Die Bestimmung verschiedener Wachstumsquellen im Rahmen eines Growth AccountingAnsatzes hängt stark von Preismaßen ab, die die Produktivität von Inputs widerspiegeln sollen. Wir zeigen, wie Preismaße den Beitrag von Investitionen zum Wachstum der Arbeitsproduktivität beeinflussen und bestimmen den Anteil dieses Beitrags, der aus verbesserter Qualität von IKT-Kapital resultiert. Bei den Preismaßen, die wir betrachten, handelt es sich um den gesamtwirtschaftlichen Kapitalertrag und den Preisverfall für IKTInvestitionsgüter. Wenn diese Maße Produktivität in einer unverzerrten Weise abbilden, entsprechen ihre Effekte denjenigen der Grenzproduktivität des Kapitals und des technologischen Fortschritts durch IKT-Investition. Die Analyse basiert auf Daten der EU KLEMS-Datenbank für sieben Länder im Zeitraum von 1990 bis 2007. Sie zielt darauf ab, die Effekte der allgemeinen Niveaus von Kapitalertrag und Verfallsrate der IKT-Preise von den Effekten zu trennen, die sich aus den Unterschieden dieser Größen zwischen Ländern, Sektoren und Zeiträumen ergeben. Während man plausiblerweise davon ausgehen kann, dass die allgemeinen Niveaus der Maße ökonomische und technologische Randbedingungen widerspiegeln, unterstellen wir, dass die Unterschiede zumindest anfälliger für Messfehler sind.

Alternativ zu den Maßen der EU KLEMS-Datenbank verwenden wir eine konstante reale Kapitalertragsrate von $4 \%$ und Preisverfallsraten für IKT-Investitionen, die dem USDurchschnitt im Zeitraum 1990 - 2007 entsprechen. In der Sensitivitätsanalyse erweisen sich die meisten Ergebnisse des Growth Accounting mit den EU KLEMS-Daten als relativ robust. Nur für den Zeitraum von 1995 bis 2000 erhalten wir mit der konstanten Kapitalertragsrate beträchtlich niedrigere Wachstumsbeiträge des Kapitals in Großbritannien und den USA. Dies führt zu höheren Beiträgen der Multifaktorproduktivität. Der Rückgang des Wachstumsbeitrags fällt für Nicht-IKT-Kapital höher aus als für IKT-Kapital. Wie die konstante Kapitalertragsrate verringern auch die alternativen IKT-Deflatoren den Einfluss von Investitionen im Vergleich zum Einfluss der Multifaktorproduktivität in Großbritannien und den USA im Zeitraum von 1995 bis 2000.

Im nächsten Schritt nehmen wir eine Zerlegung des Wachstumsbeitrags von IKTKapital in die Beiträge von Menge, Qualität und Änderung der Zusammensetzung vor. Der Beitrag einer veränderten Zusammensetzung hängt von den Änderungen der Anteile von IKT-Hardware, Software und Telekommunikationsausrüstung am gesamten IKT-Kapital ab. Wir zeigen, dass mehr als die Hälfte des Beitrags von IKT-Kapital zum Wachstum der Arbeitsproduktivität auf Änderungen der Qualität und der Zusammensetzung zurückgeht. Zwischen 2000 und 2007 liegt der Beitrag der Menge in manchen Ländern nahe null, während Ersatzinvestitionen zu einem positiven Beitrag der Qualität führen. 


\title{
Productivity of ICT and Non-ICT Capital - The Role of Rates of Return and Capital Prices
}

\author{
Thomas Niebel Marianne Saam* \\ Centre for European Economic Research (ZEW), Mannheim, Germany
}

December 2011

\begin{abstract}
We investigate the role rates of return and rates of asset price decline play in explaining sources of productivity growth in the context of a growth accounting approach. Our analysis is based on data from the EU KLEMS database for seven countries in the period of $1990-2007$. We introduce a constant rate of return to capital and a constant rate of ICT price decline across sectors, countries and time. The main result of this sensitivity analysis is that both alternative measurements somewhat downplay the role investment played relative to growth in multi-factor productivity in the UK and the US during 1995 - 2000. Moreover, we show that more than half of the ICT contribution to labor productivity growth results from growth in capital quality and composition rather than quantity.
\end{abstract}

Keywords: ICT Capital, Asset Prices, Rates of Return, Growth Accounting. JEL Classification Numbers: C43, E22, O33, O47.

\footnotetext{
*Corresponding author: Centre for European Economic Research (ZEW), P.O. Box 1034 43, 68034 Mannheim, Phone: +49-621-1235-285, Fax:-333, E-mail: saam@zew.de. This paper is written as part of the SERVICEGAP project. This project is funded by the European Commission, Research Directorate General as part of the 7th Framework Programme, Theme 8: Socio-Economic Sciences and Humanities. Grant Agreement no: 244 552. We thank Irene Bertschek, Reitze Gouma as well as participants at the SERVICEGAP midterm conference, the DEGIT XVI conference in St. Petersburg and the ICTNET workshop in Mannheim for helpful comments and suggestions. All remaining errors are ours.
} 


\section{Introduction}

Empirical studies attribute the US growth acceleration in the mid-1990s to the revolution in the field of information and communication technologies (ICT). Both the ICT producing sector and ICT investment in other sectors were larger in the US than in continental Europe. After 2000, the US continued to grow faster than many European countries, but the sources of growth shifted to a broader range of sectors. ICT-intensive service industries such as business services and trade experienced fast productivity growth (see e.g. Van Ark et al. (2008)).

Most of these studies use growth accounting, which decomposes growth in labor productivity into the contributions of ICT and non-ICT capital deepening and a residual measure of multi-factor productivity (MFP) growth. The contributions of capital deepening depend crucially on the way one measures capital and its productivity. In this paper, we ask to which extent the contributions of ICT and non-ICT capital depend on prices rather than investment quantities. If price measures correctly reflect productivity, their effects correspond to the effects of marginal productivity and embodied technological progress. In particular, we want to know to which extent the high contributions of ICT capital in some countries during 1995 - 2000 are driven by high capital remuneration and rapid increase in the quality of ICT capital goods.

We focus on two price elements that play an essential role in the computation of the contribution of capital to labor productivity growth: the rate of return to capital and the price deflation of ICT assets. Both enter the user cost of capital, which is assumed to reflect its marginal productivity. The user cost of individual assets is employed when aggregating them to ICT and non-ICT capital. The user cost of total ICT and non-ICT capital in turn enter the output elasticities that are used in growth accounting. Moreover, the ICT price deflator is used to convert nominal into real measures of ICT investment. In the standard growth accounting approach, the return to capital is computed as a residual, subtracting labor income from value added. ICT price deflators used nowadays, as those used in the EU KLEMS database, are based on hedonic methods or similar approaches that take into account the rapid quality change of IT hardware (and to a lesser extent of software and telecommunications equipment). The higher the measured quality change, the higher the increase in real ICT capital services and their contribution to growth. The change in hedonic deflators relative to general inflation represents a measure of embodied technological progress, because the difference accounts for the fact that a given amount of real monetary ICT investment becomes more productive over time.

The theoretical and practical shortcomings of available measures for the relevant rate of return and for ICT prices are well-known. Computations of capital services and contributions to growth under alternative assumptions have been undertaken in different previous studies. But there has been little systematic investigation whether the conclusions from 
cross-country growth accounting change in an economically meaningful way when introducing alternative measures of returns to capital and ICT prices. We explicitly focus on how different rates of return influence contributions to growth from ICT and non-ICT capital. Moreover, we single out embodied technological change in the ICT contribution.

In contrast to previous research, we do not intend to propose a particular improved measurement in this paper. We introduce a minimalistic measurement into a growth accounting setting and compare the results to those obtained with the EU KLEMS data. We do not argue that our measures are superior in any way. We rather consider that this exercise will improve the understanding of what drives the observed differences in the contributions of capital deepening and MFP across countries and time. The sensitivity analysis may be useful in detecting these influences, independently of the underlying reasons being measurement error or real differences in productivity and capital quality. Our aim is to disentangle the effect of the overall level of the rate of return and the overall decline in ICT prices from the effect of differences in these measures across countries, sectors and time. While it is plausible to consider that the overall level reflects economic and technological conditions, we presume that the differences are at least more prone to measurement error. Introducing a constant rate of return to capital and a constant decline in ICT investment prices, we conduct growth accounting and consider the change in aggregate and sectoral contributions to growth. In addition, we split up the ICT contributions to labor productivity growth into a quantity, a composition and a quality component. Our main results are that both the constant rate of return and the constant ICT price decline somewhat downplay the role investment played relative to growth in multi-factor productivity (MFP) in fast growing countries during 1995-2000. Moreover, we show that more than half of the ICT contribution results from growth in quality rather than quantity.

\section{Previous Literature}

We combine several approaches that have been introduced in the literature to investigate the role of rates of return, ICT investment deflators and changes in capital quality. Diewert (2001) evaluates 12 models for the measurement of capital services that differ in assumptions concerning rates of return, depreciation rates and investment price indices. In one specification he introduces a constant real rate of return of $4 \%$, which is close to the long-term OECD average. His analysis shows that rates of return and price indices are more important than depreciation rates in determining capital services. Oulton (2007) and Oulton and Rincon-Aznar (2010) propose a hybrid method of using rates of return to capital in a growth accounting framework. They suggest computing capital services using ex-ante (external) weights and the contribution to output growth using the ex-post 
(internal) income share of capital. Computing rates of return from a residual measure of capital income, Oulton and Rincon-Aznar (2010) find that they remain fairly constant across countries and time (with the exception for implausible overall magnitudes in Italy and Spain), while exhibiting implausible variation across sectors. Schreyer (2010) analyses the computation of capital services and contributions to growth with external rates of return from a theory-based perspective. As potential causes for the gap between the residual rate of return and the marginal productivity of capital he discusses mark-ups over producer cost, increasing returns to scale and unmeasured assets. His aim is to "define a computable measure of productivity growth while allowing for the fact that it may reflect more than pure technology shifts" (p.20). We will follow this approach by introducing an external rate of return to capital and compute a MFP measure that corresponds to what he terms apparent multi-factor productivity. Apparent MFP is derived assuming that the cost function is linearly homogeneous in inputs and non-decreasing. This assumption does not imply the usually imposed constant returns to scale of the production function. Factor markets are assumed to be competitive while firms may charge a variable mark-up over costs in selling their products. In addition, the approach allows for the presence of unmeasured inputs. Under these assumptions, it is possible to derive a cost-based MFP measure using an external rate of return to capital. Apparent MFP not only includes the effects of technological progress shifting the production function but also the effects of non-constant returns to scale, mark-ups and unmeasured inputs. Under additional assumptions, it is possible to disentangle these effects and identify a measure of pure technological change. Implementing several of these measures, Schreyer (2010) finds only a small difference to apparent MFP and recommends the latter measure as a pragmatic and relatively robust way of measuring MFP. Inklaar (2010) considers the role of land, inventories and intangibles in calculating capital services. He proposes to use a measure of the weighted average cost of capital for the rate of return, taking into account both equity cost and debt cost. Previous studies used simpler measures, which might not reflect the cost of capital as precisely but are easier to implement in a context with many sectors and countries.

With regard to ICT deflators, Schreyer (2002) advocates the use of price deflators "harmonized" to the one in the U.S., where quality-adjusted measures are considered to be best implemented. Harmonization means that the decline of ICT prices relative to non-ICT capital prices is assumed to be identical in all countries, following the movement observed in the U.S. This method is also used in the EU KLEMS database for those countries without adequate national measurement of ICT prices. If this approach is used at the level of different ICT categories (hardware, software, telecommunications), aggregate real price decline may still differ across countries as a result of a different mix in ICT capital. If aggregate ICT deflators are used, these differences are masked as well as potential influences of national market structures. Schreyer (2010) argues that the 
possible measurement error due to the usage of a harmonized price index is still smaller than the bias arising from comparing capital services computed with national deflators. When it comes to measuring GDP, the problem is not as important according to Schreyer (2002), since the effects of different deflators on domestically produced and imported ICT are partly offsetting. Sectoral output may, however, be affected in a more notable way.

Growth accounting does not offer insight into the deep causes that represent exogenous parameters in theoretical models. In particular, it does not account for determinants of capital accumulation. Embodied technological change has been modeled in the context of equilibrium growth accounting, which takes into account the response of investment to technological change. In this paper, we compute a measure of embodied technological change only in the context of statistical growth accounting (for a discussion of statistical versus equilibrium growth accounting, see Cummins and Violante (2002)). The aim is to obtain results that remain comparable to standard growth accounting, which despite its limited scope still plays an influential role in informing economic policy.

In order to assess the contribution of ICT capital quality, we rely on an approach first mentioned by Jorgenson (2001). Colecchia and Schreyer (2002) describe this method in more detail and apply it to a set of nine OECD countries. They evaluate changes in the quality of aggregate capital stemming from the shift in its composition towards highly productive but more short-lived assets. The effect of this compositional change is obtained as the difference between the change in capital services and the change in the capital stock, or, in other words, as the difference between measures of growth in capital input based on user costs and based on nominal asset shares. In addition, Bassanini and Scarpetta (2002) identify the effect that results from improved quality of capital through technological progress. These quality changes within categories of assets are measured by comparing the evolution of hedonic asset prices to the evolution of real acquisition prices.

\section{Data and Growth Accounting Methodology}

\subsection{Basic Framework}

The main data source used for our research is the November 2009 release of the EU KLEMS database. ${ }^{1}$ It consists of output data on a detailed industry level and, more importantly, in-depth capital input data for eight different types of assets. They are usually grouped into ICT (hardware, software, telecommunications) and non-ICT assets (machinery etc.). The seven countries with sufficient coverage of input and price data for our analysis are Australia, Austria, Germany, Italy, Spain, UK and US. Time series for Germany start in 1991.

\footnotetext{
${ }^{1}$ See O'Mahony and Timmer (2009).
} 
Under the usual assumptions of competitive markets and constant returns to scale, industry-specific growth in real value added may be decomposed into the weighted sum of growth of inputs plus growth in multi-factor productivity $M F P$ :

$$
\Delta \ln Y_{j}=\bar{v}_{j}^{L} \Delta \ln L_{j}+\bar{v}_{j}^{I C T} \Delta \ln K_{j}^{I C T}+\bar{v}_{j}^{N I C T} \Delta \ln K_{j}^{N I C T}+\Delta \ln M F P_{j}
$$

where $L_{j}$ stands for labor input in sector $j, K_{j}^{I C T}$ for ICT capital input and $K_{j}^{N I C T}$ for non-ICT capital input. Instead of output growth, we may use a similar expression for labor productivity growth $y$, which is derived as output $Y$ over hours worked $H$ :

$$
\Delta \ln y_{j}=\bar{v}_{j}^{L} \Delta \ln l_{j}^{L}+\bar{v}_{j}^{I C T} \Delta \ln k_{j}^{I C T}+\bar{v}_{j}^{N I C T} \Delta \ln k_{j}^{N I C T}+\Delta \ln M F P_{j}
$$

where $\Delta \ln l_{j}^{L}$ is the growth rate of labor input per hour, $\Delta \ln k_{j}^{I C T}$ and $\Delta \ln k_{j}^{N I C T}$ the growth rate of ICT and non-ICT capital per hour worked. The two period average share of ICT capital compensation in total factor compensation is calculated as follows:

$$
v_{j}^{I C T}=\frac{\sum_{k \in I C T} q_{k, j, t} A_{k, j, t}}{\sum_{k \in I C T} q_{k, j, t} A_{k, j, t}+\sum_{k \in N I C T} q_{k, j, t} A_{k, j, t}+L A B_{j, t}}
$$

where $L A B_{j, t}$ denotes labor compensation in industry $j, q_{k, j, t}$ user cost of asset $k$ and $A_{k, j, t}$ real stock of asset $k$. Shares of other factors of production are obtained in an analogous way. If we use external measures of capital compensation, this leads to a cost-based measure of MFP that can be identified under the assumptions described in Schreyer (2010).

When aggregating over industries, we employ the direct aggregation approach of growth accounting as in Inklaar et al. (2005):

$$
\Delta \ln y=\sum_{j} \bar{v}_{j}^{Y}\left(\bar{v}_{j}^{L} \Delta \ln l_{j}^{L}+\bar{v}_{j}^{I C T} \Delta \ln k_{j}^{I C T}+\bar{v}_{j}^{N I C T} \Delta \ln k_{j}^{N I C T}+\Delta \ln M F P_{j}\right)+R
$$

where $\bar{v}_{j}^{Y}$ is the two period average share of industry $j$ in nominal aggregate value added. The term $R$ is called reallocation of hours, which incorporates the difference between the share of an industry in aggregate value added and in hours worked. The industry specific growth rate of ICT capital services is calculated as follows: ${ }^{2}$

$$
\Delta \ln K_{j, t}^{I C T}=\ln K_{j, t}^{I C T}-\ln K_{j, t-1}^{I C T}=\sum_{k \in I C T} \bar{w}_{k, j, t}^{I C T} \Delta \ln A_{k, j, t}
$$

\footnotetext{
$\overline{2}$ Similar calculations are used for non-ICT capital.
} 
where $\bar{w}_{k}^{I C T}$ denotes the two-period average share of asset $k$ in ICT capital compensation:

$$
w_{k, j, t}^{I C T}=\frac{q_{k, j, t} A_{k, j, t}}{\sum_{k \in I C T} q_{k, j, t} A_{k, j, t}}
$$

To calculate the shares in capital compensation $\bar{w}_{k}$ as in equation (6) and $\bar{v}_{j}^{I C T}$ as in equation (3) we need values for the user cost $q_{j}$ of asset $k$ at time $t:^{3}$

$$
q_{k, j, t}=p_{k, j, t-1}^{I} i_{j, t}+p_{k, j, t}^{I} \delta_{k, j}-\left[p_{k, j, t}^{I}-p_{k, j, t-1}^{I}\right]
$$

Equation (7) comprises the nominal rate of return $i$, the rate of depreciation $\delta$ and the asset revaluation term $p_{k, t}-p_{k, t-1} \cdot{ }^{4}$

The real capital stock is calculated using the perpetual inventory method (PIM):

$$
A_{k, j, t}=\left(1-\delta_{k, j}\right) A_{k, j, t-1}+I_{k, j, t} / p_{k, j, t}
$$

with $I_{k, j, t}$ the nominal investment and $p_{k, j, t}$ the hedonic investment price index of asset $k$ at time $t$.

\subsection{Specifications Used in Sensitivity Analysis}

The sensitivity analysis of the contributions of ICT capital, non-ICT capital and multifactor productivity to labor productivity under alternative rates of return in equation (7) is carried out using two different nominal rates of return $i_{j, t}$ :

1. The internal rate of return of the EU KLEMS database

This rate of return is calculated in a two-step procedure via an ex-post method. The first step consists of computing the industry-specific total capital compensation, which is obtained as a residual:

$$
C A P_{j, t}=V A_{j, t}-L A B_{j, t}
$$

where $V A$ denotes value added and $L A B$ labor compensation. The nominal rate of

\footnotetext{
3 See Jorgenson (2005) pages 154-155.

${ }^{4}$ In practice, we follow EU KLEMS and smooth the asset revaluation term of the user costs formula: $q_{k, j, t}=p_{k, j, t-1}^{I} i_{j, t}+p_{k, j, t}^{I} \delta_{k, j}-0.5\left(\ln \left(p_{k, j, t}\right)-\ln \left(p_{k, j, t-2}\right)\right) p_{k, j, t-1}$.
} 
return $i$ for industry $j$ is then defined as:

$$
i_{j, t}=\frac{C A P_{j, t}+\sum_{k} p_{k, j, t}^{I}-p_{k, j, t-1}^{I} A_{j, k, t}-\sum_{k} p_{j, k, t}^{I} \delta_{j, k} A_{j, k, t}}{\sum_{k} p_{j, k, t-1} A_{j, k, t}}
$$

where $p_{j, k, t}^{I}, \delta_{j, k}$ and $A_{j, k, t}$ are the investment price index, the depreciation rate and the real stock of asset $k$.

2. A $4 \%$ external real rate of return plus country-specific inflation

Our approach for an external rate of return is based on a $4 \%$ real rate of return ${ }^{5}$ combined with a 5-year centered moving average growth rate of the consumer price index $\left(\mathrm{CPI}^{6}\right)$ :

$$
i_{t}=0.04+\sum_{s=-2}^{s=+2} \Delta C P I_{t-s}
$$

This goes back to Diewert (2001) and does not lead to industry-specific rates of return.

Our second focus is on the sensitivity of growth accounting results to different ICT investment price indices $p_{k, j, t}$. They appear in equations (7), (8) and (10) of the growth accounting setting. Again we first consider the values from EU KLEMS. As alternative measures we introduce two economy-wide price indices for IT, CT and software investments, which are inspired by Oulton's (2010) calibration. Thus, we conduct growth accounting with three specifications:

1. EU KLEMS sector-specific investment price index

2. A constant decline in IT (20\%), CT (5\%) and software (4\%) investment price indices plus the country-specific growth rate of the value added deflator

3. A constant decline in IT, CT and software investment price indices of $10 \%$ plus the country-specific growth rate of the value added deflator

The constant values in specification 2 are obtained from the mean price change for IT, $\mathrm{CT}$ and software investment relative to the mean change in the value added deflator in the US for the period 1990-2007. In specification 3, the $10 \%$ decline is the growth rate of the combined ICT price index relative to the mean change in the value added deflator in the US. ${ }^{7}$ In order to obtain ICT output and input measures consistently, we need to adjust output prices for ICT-producing industries in cases 2 and 3 . We follow the method

\footnotetext{
${ }^{5}$ We checked the robustness of our results using a $3 \%$ respectively $6 \%$ real rate of return.

6 Source: OECD (2010).

7 The exact values are $-0.20209,-0.0479$ and -0.0374 for case 2 and -0.10165 for case 3 and are based on EU KLEMS data.
} 
by Inklaar et al. (2005), who apply U.S. double-deflated value added deflators adjusted for differences in overall price levels: ${ }^{8}$

$$
\Delta \ln V A \_P_{N A C E 30-33}^{X}=\Delta \ln \overline{V A \_P}{ }_{N A C E 30-33}^{U S}-\left(\Delta \ln V A \_P^{U S}-\Delta \ln V A \_P^{X}\right)
$$

where $\triangle \ln V A \_P P_{N A C E}^{X} 30-33$ denotes the growth rate of value added deflator of industries $30-33$ and $\Delta \ln V A_{-} P^{X}$ the total economy growth rate of value added deflator in country $X . \Delta \ln \overline{V A \_}_{N A C E 30-33}^{U S}$ is the geometric mean of value added deflator growth rates in industry $30-33$ in the US. The average decline is about $9 \%$ for the period $1990-2007$.

In addition to the discussion about alternative investment price indices, we decompose the contributions of ICT capital to labor productivity growth into changes in quantity, asset composition and quality of ICT capital. This is related to the use of hedonic price indices, which control for differences in quality. The real IT, CT and software capital stock based on (non-hedonic) acquisition prices is calculated as follows:

$$
S_{k, j, t}=\left(1-\delta_{k, j}\right) S_{k, j, t-1}+I_{k, j, t} / p_{N I C T, j, t}
$$

with $p_{N I C T, j, t}$ being the investment price index of non-ICT capital goods. We assume that $p_{N I C T, j, t}$ is a non-hedonic price index. With average price index growth rates between $1.2 \%$ (DE) and $4.3 \%$ (ES) for the period $1990-2007$, this seems to be an appropriate assumption. Following approaches by Colecchia and Schreyer (2002) and Bassanini and Scarpetta (2002), the weights for the calculation of a combined ICT capital stock index are now based on assumed purchase prices rather than on user costs as in equation (6):

$$
z_{k, j, t}^{I C T}=\frac{p_{N I C T, j, t} S_{k, j, t-1}}{\sum_{k \in I C T} p_{N I C T, j, t} S_{k, j, t-1}} .
$$

The industry-specific growth rate of non-hedonic ICT capital stock $\Delta \ln S_{j, t}^{I C T}$ (i.e. capital quantity) is therefore calculated as follows:

$$
\Delta \ln S_{j, t}^{I C T}=\ln S_{j, t}^{I C T}-\ln S_{j, t-1}^{I C T}=\sum_{k \in I C T} \bar{z}_{k, j, t}^{I C T} \Delta \ln S_{k, j, t}
$$

In order to separate quality and compositional effects we need to calculate industry-specific growth rates of quality adjusted (hedonic) ICT capital stocks $\Delta \ln H S_{j, t}^{I C T}$ :

$$
\Delta \ln H S_{j, t}^{I C T}=\ln H S_{j, t}^{I C T}-\ln H S_{j, t-1}^{I C T}=\sum_{k \in I C T} \bar{b}_{k, j, t}^{I C T} \Delta \ln A_{k, j, t}
$$

\footnotetext{
$\overline{8}$ Inklaar et al. (2005) page 510, ICT output is defined as NACE revision $1.130-33$.
} 
with $\Delta \ln A_{k, j, t}$ the productive stock of asset $k$ based on quality-adjusted prices as defined in equation (8). In contrast to the growth rate of ICT capital services defined in equation (5) the aggregation to hedonic ICT capital stock is based on nominal asset shares $b_{k, j, t}^{I C T}$ :

$$
b_{k, j, t}^{I C T}=\frac{p_{k, j, t} A_{k, j, t-1}}{\sum_{k \in I C T} p_{k, j, t} A_{k, j, t-1}} .
$$

The growth rate of ICT capital quality $\Delta \ln Q_{j, t}^{I C T}$ is derived as a residuum:

$$
\Delta \ln Q_{j, t}^{I C T}=\Delta \ln H S_{j, t}^{I C T}-\Delta \ln S_{j, t}^{I C T}
$$

ICT capital quality is defined as the difference between the growth rate of ICT capital stock based on hedonic prices $\Delta \ln H S_{j, t}^{I C T}$ and the growth rate of ICT capital stock based on non-hedonic prices $\Delta \ln S_{j, t}^{I C T}$.

Changes in the composition of ICT capital $\Delta \ln C_{j, t}^{I C T}$ (i.e. changes in the share of different ICT assets) are again calculated as a residuum:

$$
\Delta \ln C_{j, t}^{I C T}=\Delta \ln K_{j, t}^{I C T}-\Delta \ln H S_{j, t}^{I C T}
$$

This is the difference between the growth rate of ICT capital services $\Delta \ln K_{j, t}^{I C T}$ and the growth rate of quality adjusted ICT capital stock $\Delta \ln H S_{j, t}^{I C T}$. The sum of $\Delta \ln S_{j, t}^{I C T}$ (ICT capital quantity), $\Delta \ln Q_{j, t}^{I C T}$ (ICT capital quantity) and $\Delta \ln C_{j, t}^{I C T}$ (compositional change) equals the growth rate of ICT capital services.

\section{Results}

In this section, we discuss the growth accounting results under alternative rates of return and alternative investment prices as well as a breakdown of the ICT contribution into quality change, compositional change and quantity change. We present diagrams with results at the level of the market economy for the periods $1990-1995,1995-2000$ and 2000-2007. Additional tables in the Appendix summarize results for the goods producing sector and the market services sector. ${ }^{9}$ The sector electrical and optical equipment is listed separately within goods production because, analogous to ICT capital prices, we change ICT output deflators in our sensitivity analysis. In order to get an impression of the effect of sectoral contributions at the aggregate level, tables A.10 to A.12 list the sectoral contributions to growth in labor productivity in the market economy. The numbers clearly

\footnotetext{
${ }^{9}$ A further breakdown of all results for sub-sectors of market services is available upon request. Table A.13 lists NACE 1.1. codes of the sectoral breakdown used.
} 
show the transition to a more service-based growth that has been discussed in much of the literature. Between 1990 and 1995, the contribution to labor productivity growth is higher in goods production than in service production in all countries except Australia. Between 1995 and 2000, the contribution to growth from services is higher in most countries. In the UK and the US, it is more than the double of the contribution to growth from goods production. During $2000-2007$, the contribution from services remains high in both countries, while it is about equal to less than the contribution from goods production in the five other countries.

\subsection{Different Rates of Return}

We compare growth accounting results with the EU KLEMS internal rate of return and an external real rate of return of $4 \%$. Figure A.1 displays the nominal returns based on EU KLEMS and the external rate. Internal rates are always higher, implying that internal real rates exceed $4 \%$. The highest nominal internal rates of return are observed in Spain and the US. Growth accounting results show that with the external rate of return, the contribution of capital to labor productivity growth is lower in most cases. The differences between both variants turn out to be higher for the contribution of nonICT capital. For the ICT contribution, rates of return make less of difference because its user cost is dominated by the decline in ICT prices. If we regard our sensitivity analysis as an exercise to gauge the size of potential measurement error, differences in the capital contribution of around 5 to 30 percent appear large (Figures 4.1 to 4.3). But they remain small in most cases when compared to the differences in growth of labor productivity and MFP across countries. For the period 1990 - 1995, differences arising from the external rate of return are small at the level of the market economy in all countries except Spain and, to a minor extent, the US.

We observe the most visible effect during 1995 - 2000 in the US and the UK (Figure 4.2 and Table A.2). In this period, the decline in the capital contribution is also notable for ICT. In US market services, the average decline in the contributions of ICT and non-ICT capital between 1995 and 2000 attains the same value of 0.18 percentage points (with, however, a higher overall level of the ICT contribution). With the external rate of return, MFP in US and UK market services increases by 0.31 and 0.39 percentage points. A similar increase, but at a much lower overall level, can be observed in Italy. In Germany, negative MFP growth in market services is reduced from -0.30 to -0.09 percentage points. In the other countries, the increase in market services MFP growth turns out to be lower. Looking at individual services industries, ${ }^{10}$ we find that a broad range of services share the increase in MFP under the external rate of return in the UK. Changes in MFP growth above 0.3 percentage points are observed in trade, hotels and

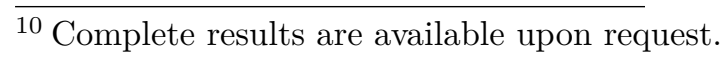


restaurants, financial intermediation and business services. In the US, large changes in services MFP growth are confined to financial intermediation and business services. In the business services sector of both countries, the ICT contribution to labor productivity growth declines by more than 0.4 percentage points with the external rate of return. Meanwhile, the level of the contribution remains high at more than 1.5 percentage points.

Taken at face-value, the results for $1995-2000$ would attenuate the frequently emphasized switch from ICT-driven growth before 2000 to MFP-driven growth afterwards. The results from our specification attribute more of labor productivity growth in the UK and the US between 1995 and 2000 to MFP growth. With the EU KLEMS internal rate of return, the ICT contribution exceeds the MFP contribution by more than 0.3 percentage points (see Table A.2). With the $4 \%$ external rate of return, both contributions are of similar magnitude. In this context, higher MFP growth is fueled to a large extent by a decline in the non-ICT contribution. The high capital contribution observed with an internal rate of return in UK, US and Italy results partly from a real rate of return that exceeds the benchmark value of $4 \%$. During the period $2000-2007$, moving to an external rate of return does not have a notable effect on productivity contributions in the overall market economy (Table A.3). While differences between the internal and external rate of return are not smaller than in the previous period (see Figure 4.3), the overall capital contribution is quite small and changes in the sensitivity analysis are also small in absolute value. Goods production in Australia, UK and the US experiences a relatively high effect. The overall change in the market economy is highest in Italy and Spain, where internal rates of return are known to be implausible (Oulton and Rincon-Aznar (2010)). Sensitivity analysis with other rates of return (real 3\%,6\%, average of short and long-term interest rate - results available upon request) shows that the impact of different rates on the capital contribution may be high relative to the contribution itself, but it is often small relative to aggregate labor productivity growth, especially before 1995 and after 2000 . 
Figure 4.1: Contribution to labor productivity growth for different rates of return - MARKET ECONOMY

\section{Contributions to labor productivity growth}

1990-1995

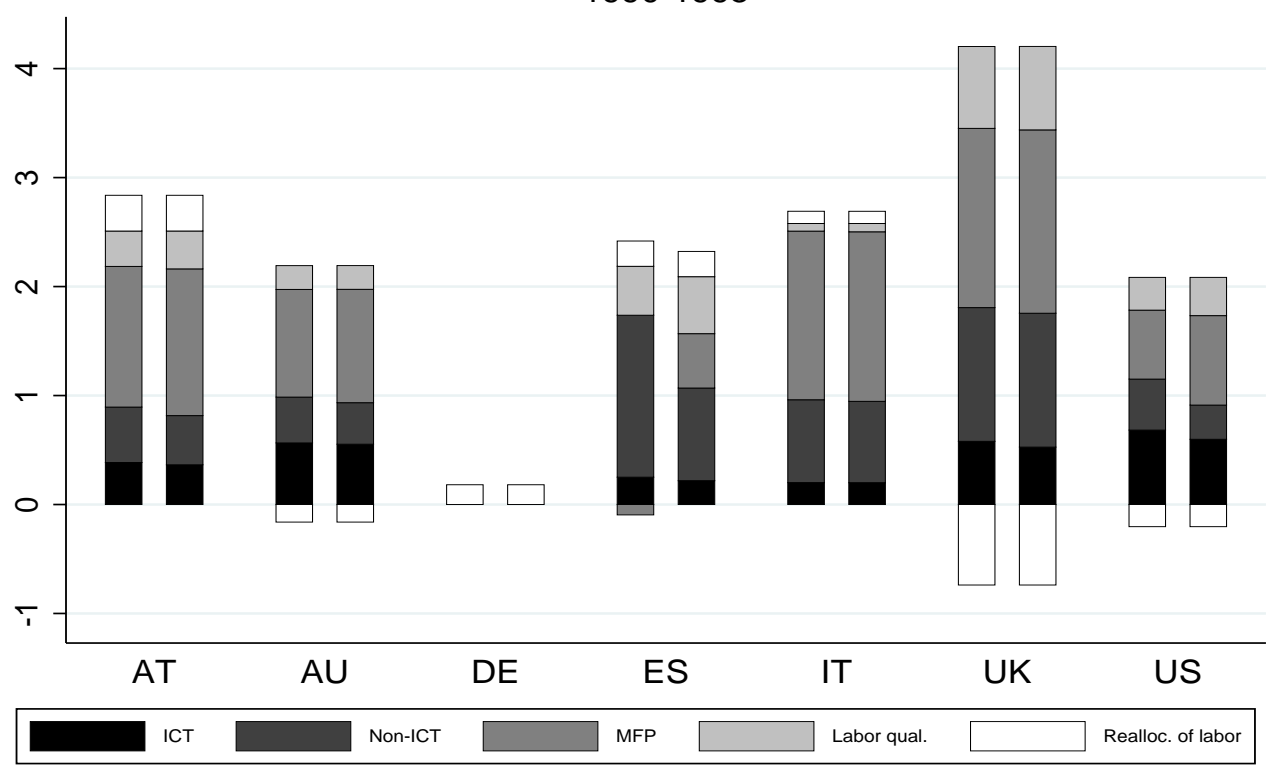

Notes: $\operatorname{Bar}(1)$ : internal rate of return $\operatorname{Bar}(2): 4 \%+$ moving average CPI growth rate. Source: EU KLEMS, November 2009 release. Own calculations.

Figure 4.2: Contribution to labor productivity growth for different rates of return - MARKET ECONOMY

\section{Contributions to labor productivity growth}

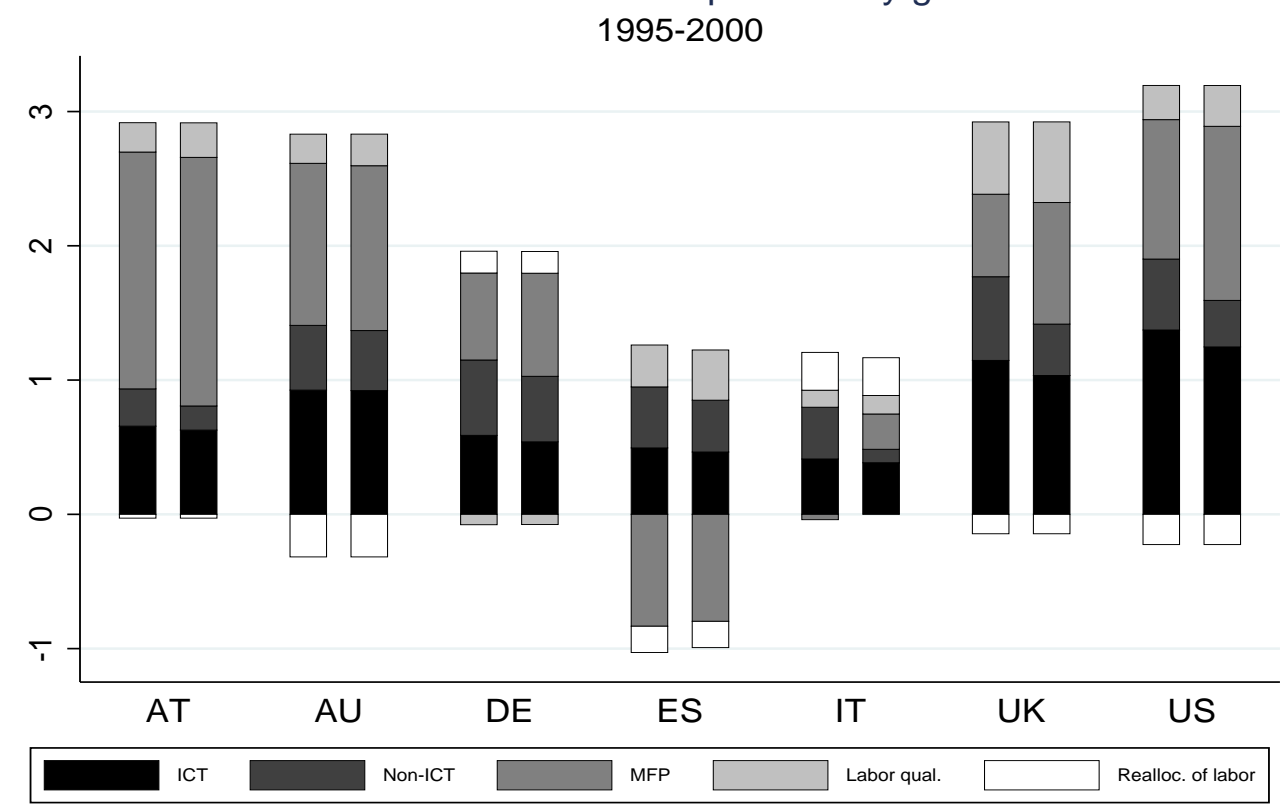

Notes: $\operatorname{Bar}(1)$ : internal rate of return $\operatorname{Bar}(2): 4 \%+$ moving average CPI growth rate.

Source: EU KLEMS, November 2009 release. Own calculations. 
Figure 4.3: Contribution to labor productivity growth for different rates of return - MARKET ECONOMY

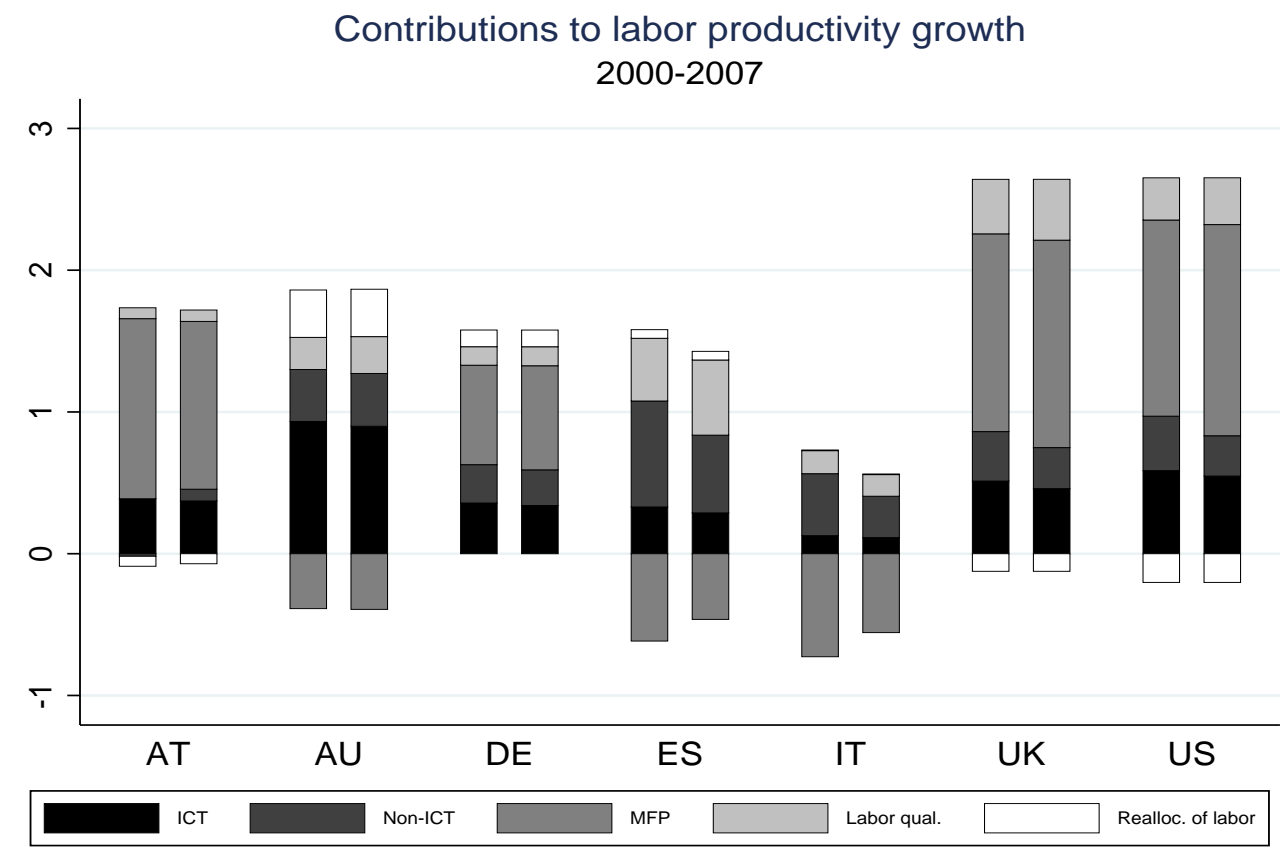

Notes: $\operatorname{Bar}(1)$ : internal rate of return $\operatorname{Bar}(2): 4 \%+$ moving average CPI growth rate. Source: EU KLEMS, November 2009 release. Own calculations.

\subsection{Different ICT Investment Prices}

We now consider the effect of replacing the ICT investment price indices from EU KLEMS with average US values of price decline relative to the US value added deflator. We discuss two variants: the first introduces different price declines for IT hardware, software and telecommunications equipment, the second applies a unique rate of price decline of $10 \%$ to all ICT capital goods. Figure A.2 compares nominal price declines for IT hardware, software and communication technology resulting from the three specifications. The aim of this sensitivity analysis is to eliminate differences in the ICT contributions that result solely from differences in price decline, that is from presumed differences in embodied technical progress. When introducing a constant price decline to ICT inputs, we also introduce a constant price decline to the output of ICT production, which changes labor productivity. Since data are only available for the aggregated sector of the production of electrical and optical equipment, our adjustment should only be seen as a rough approximation. The columns $L P^{* *}$ and $L P^{* * *}$ in tables A.4 to A.6 represent labor productivity with average US price decline for the electrical and optical equipment sector corrected for the difference in inflation between the US and the respective country.

If average US investment price decline implies stronger technical progress than price decline in a given country or period, our procedure will raise ICT contributions. On the other hand, if output in ICT production is lower with national deflators, introducing average US price decline will raise it and, ceteris paribus, raise multi-factor productivity. In 
the period of $1990-1995$, the effect on labor productivity growth in the sector of electrical and optical equipment turns out to be a lot higher than the effect on ICT contributions (Figure 4.4 and Table A.4). Since the hedonic ICT prices in the US decline faster after 1995, taking the average over 1990 - 2007 raises price decline and ICT contributions before 1995. During 1995 - 2000, introducing average US price decline again has a high effect on labor productivity growth in the optical and electrical equipment sectors of all other countries (Figure 4.5). This effect mainly drives the observed increases in market sector MFP growth (Table A.4). The effect on labor productivity in the ICT producing sector in the US itself is negative in this period. Meanwhile, we observe little systematic change in the ICT contributions to labor productivity growth. In most countries, the ICT contribution is lower with at least one variant of constant price decline. In Germany and Spain, the ICT contribution resulting from EU KLEMS data is higher than the ones obtained from both variants of constant price decline. The largest decreases of the ICT contribution are observed in Australia and the US. In Australia, changes in goods production and market services are of approximately equal size. In the US, the decline is mainly driven by market services (Table A.5). Looking at individual services industries reveals that this decline is strongest in financial intermediation and business services (results not reported). During 2000 - 2007, high increases in labor productivity growth from adjusting deflators in ICT production output are observed in Austria, Germany and Italy (Figure 4.6 and Table A.6, first two columns). These increases entail an increase in MFP, which is also observed to a lower extent in Australia, Spain and the UK. MFP in the US market economy declines with the introduction of our averaged price deflators, since labor productivity growth remains nearly unchanged and the ICT contribution rises.

As the sensitivity analysis with different rates of return, the results with alternative investment deflators show a lower contribution of capital deepening to growth in the US between 1995 and 2000 than the results from EU KLEMS data. Since, in addition, US MFP turns out to be lower after 2000, the alternative measures again reduce the contrast between ICT-based growth before 2000 and MFP-based growth afterwards. In both cases, the effect in market services plays an important role. However, the parallel between sensitivity analysis in rates of return and in investment prices only holds for the US, not for the UK. It may be related to the fact that we use average US price decline as a benchmark. The results have to be interpreted with some caution, since we did not harmonize prices for ICT imports and intermediates, which may have partially offsetting effects. The contribution of non-ICT is virtually unaffected by different ICT deflators. A few slight differences arise from changes on total capital income and thus in the income share of non-ICT capital. 
Figure 4.4: Contribution to labor productivity growth for different investment prices - MARKET ECONOMY

\section{Contributions to labor productivity growth}

1990-1995

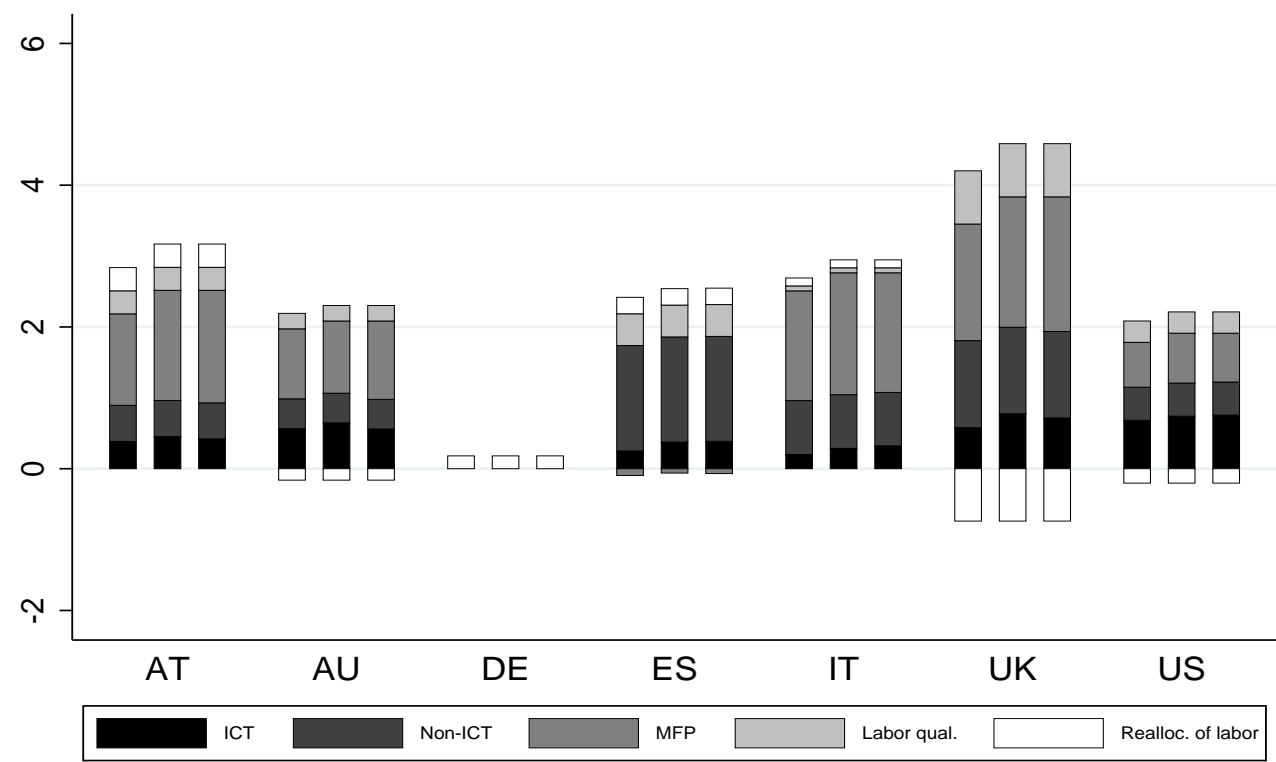

Notes: Bar(1): EU KLEMS investment prices Bar(2): $-5 \%$ (CT), -20\% (IT), -4\% (Software) +GDP deflator Bar(3): $-10 \%$ + GDP deflator.

Source: EU KLEMS, November 2009 release. Own calculations.

Figure 4.5: Contribution to labor productivity growth for different investment prices - MARKET ECONOMY

$$
\begin{gathered}
\text { Contributions to labor productivity growth } \\
1995-2000
\end{gathered}
$$

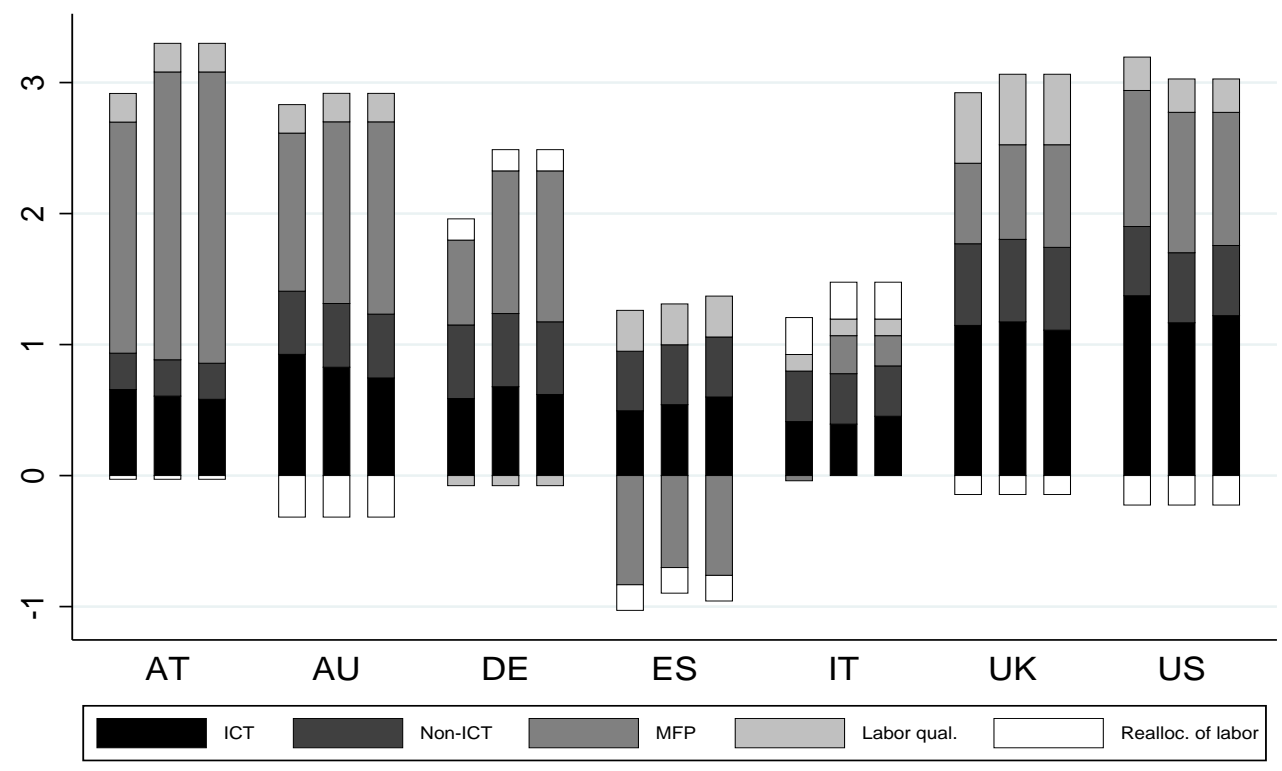

Notes: Bar(1): EU KLEMS investment prices Bar(2): $-5 \%$ (CT), -20\% (IT), -4\% (Software) +GDP deflator Bar(3): $-10 \%$ + GDP deflator.

Source: EU KLEMS, November 2009 release. Own calculations. 
Figure 4.6: Contribution to labor productivity growth for different investment prices - MARKET ECONOMY

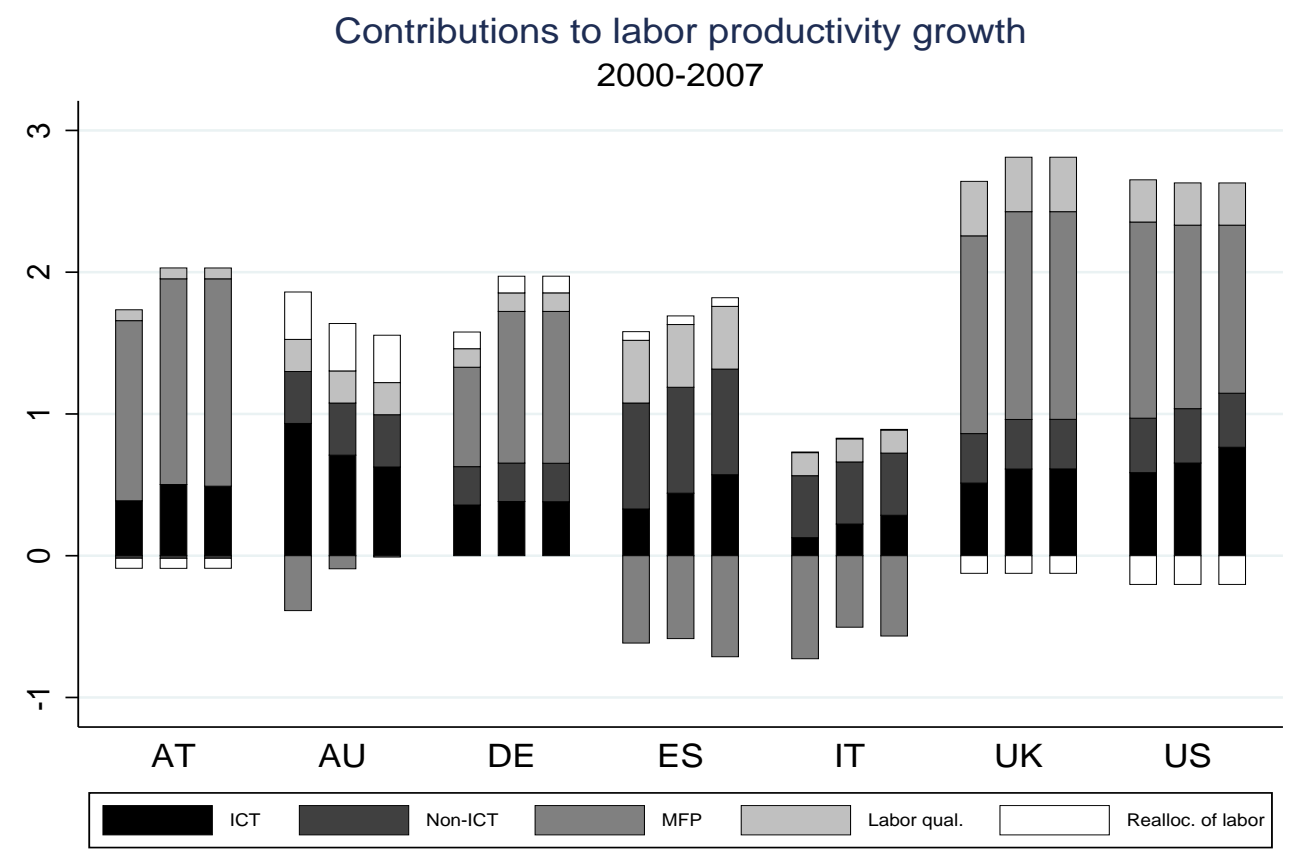

Notes: Bar(1): EU KLEMS investment prices Bar(2): $-5 \%$ (CT), -20\% (IT), -4\% (Software) +GDP deflator Bar(3): $-10 \%$ + GDP deflator.

Source: EU KLEMS, November 2009 release. Own calculations.

\subsection{Contributions of ICT Capital Quantity, Composition and Quality}

In the previous paragraph we examined how alternative ICT deflators representing alternative rates of embodied technological progress affect the contribution of ICT and MFP to labor productivity growth. In this paragraph we make further use of the information contained in ICT deflators in order to break down the ICT contribution into embodied technological progress (quality change), compositional change and quantity change. We do this for all three ICT deflators used.

The most striking observation in all periods is that the joint contribution of quality and compositional change tends to exceed the contribution of quantity by the factor two or more (Figures 4.7 to 4.9). Some countries even experience a growth in ICT quantity close to zero while quality increases through the replacement of old capital (Austria, Germany and Italy exhibit a contribution of quantity change close to zero in 2000 - 2007, while the contribution of quality change lies around $0.2-0.3$ percentage points.). Our results underline the importance of correctly reflecting the productive capacities of ICT in hedonic price measurement. The largest relative contributions of ICT quantity are measured in the UK and in the US between 1990 and 2000. During 1995 - 2000, the overall ICT contribution in these countries was very high. During 1990 - 1995, the contributions are similar to those observed in $2000-2007$. But in the latter period, the share of ICT 
quantity in the total contribution is much lower.

Moreover, we observe that constant price decline across the three ICT assets largely reduces compositional change, although it does not completely eliminate it (except in 2000 to 2007, where it virtually turns zero in the third variant considered). Compositional change turns out to be small compared to the other two components. This is not surprising, since we consider compositional change only within ICT capital. Still, there is a clear pattern with contributions ranging from 0.01 to 0.12 percentage points in the first period (with the exception of the high value of 0.22 percentage points observed in Australia), contributions from 0.10 to 0.30 percentages points during $1995-2000$ and a decline to the range of 0.01 to 0.10 percentage points (again with an outlier of 0.15 in Australia) after 2000 (Tables A.7 to A.9). It is likely that the high values for $1995-2000$ result from the decline in the share of traditional communication technology in total ICT capital. The movements of the ICT quality contributions across the three variants of deflators essentially reflect the changes in the overall ICT contribution discussed in the previous paragraph.

Figure 4.7: Contribution to labor productivity growth by ICT capital quality, composition and quantity - MARKET ECONOMY

$$
\begin{gathered}
\text { Contributions to labor productivity growth } \\
\text { 1990-1995 }
\end{gathered}
$$

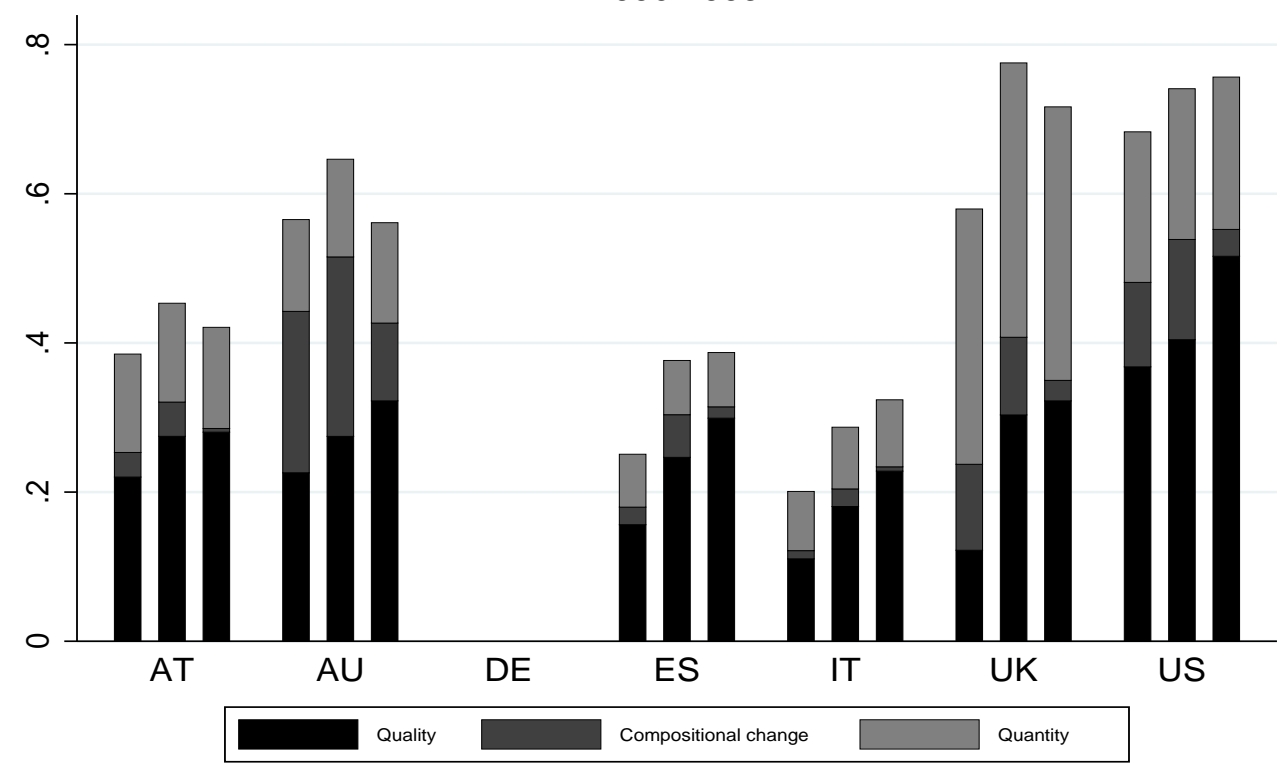

Notes: Bar(1): EU KLEMS investment prices Bar(2): $-5 \%$ (CT), $-20 \%$ (IT), $-4 \%$ (Software) + GDP deflator Bar(3): $-10 \%$ + GDP deflator.

Source: EU KLEMS, November 2009 release. Own calculations. 
Figure 4.8: Contribution to labor productivity growth by ICT capital quality, composition and quantity - MARKET ECONOMY

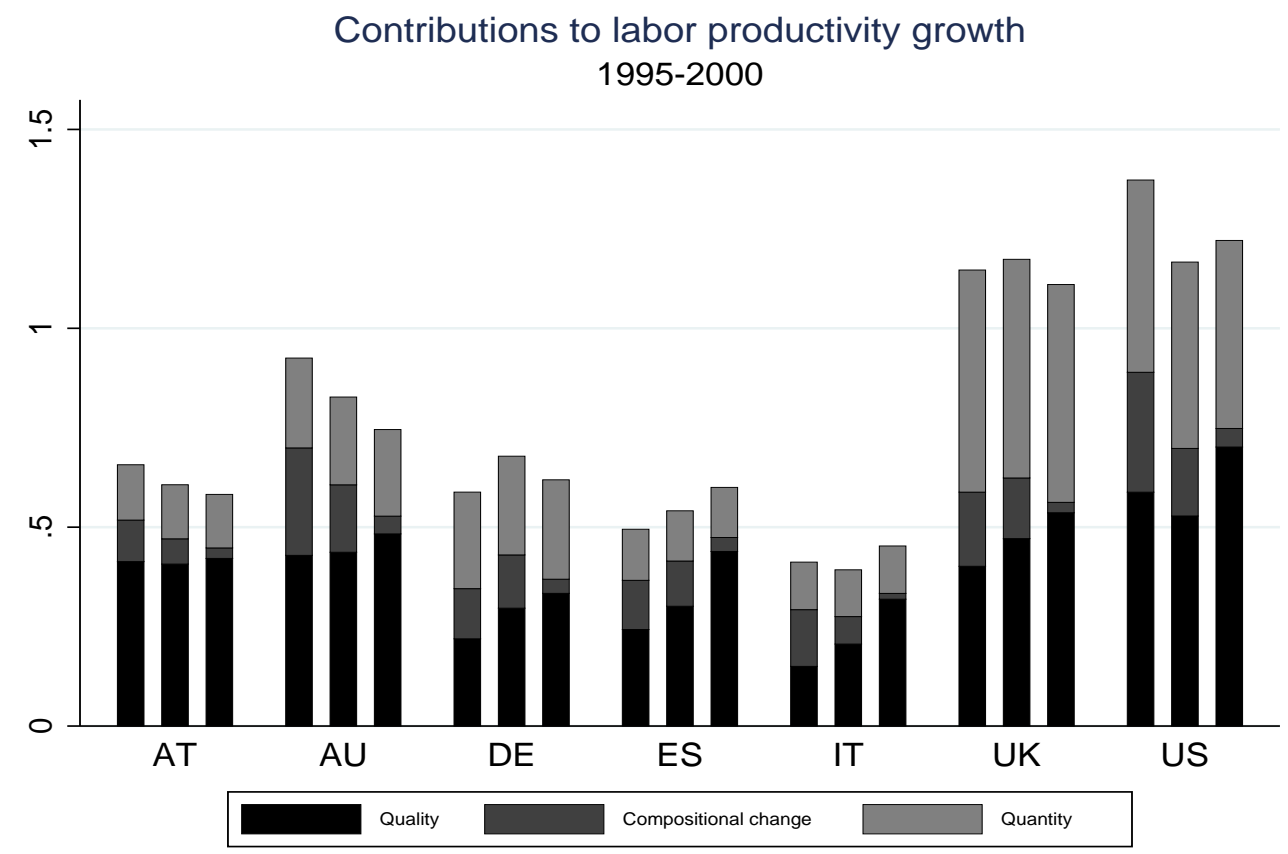

Notes: Bar(1): EU KLEMS investment prices Bar(2): $-5 \%$ (CT), -20\% (IT), $-4 \%$ (Software) +GDP deflator Bar(3): $-10 \%$ + GDP deflator.

Source: EU KLEMS, November 2009 release. Own calculations.

Figure 4.9: Contribution to labor productivity growth by ICT capital quality, composition and quantity - MARKET ECONOMY

$$
\begin{aligned}
& \text { Contributions to labor productivity growth } \\
& \qquad 2000-2007
\end{aligned}
$$

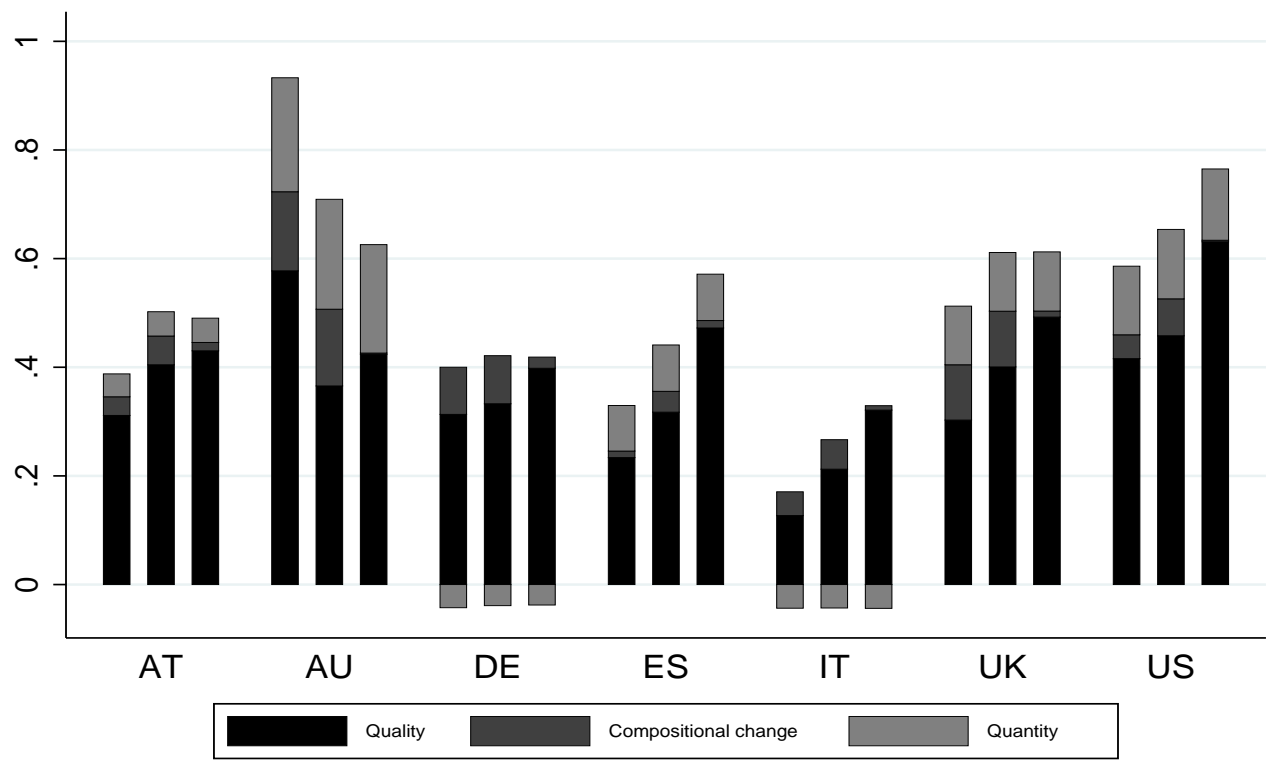

Notes: Bar(1): EU KLEMS investment prices Bar(2): -5\% (CT), -20\% (IT), -4\% (Software) + GDP deflator Bar(3): $-10 \%$ + GDP deflator.

Source: EU KLEMS, November 2009 release. Own calculations. 


\section{Conclusion and Outlook}

We have investigated the role rates of return, rates of ICT asset price decline and changes in ICT quality play in explaining sources of productivity growth within a growth accounting framework. In order to conduct sensitivity analysis, we introduced a constant rate of return to capital and a constant rate of ICT price decline across sectors, countries and time. The main result is that both alternative measurements somewhat downplay the importance of investment relative to growth in multi-factor productivity (MFP) in fast growing countries of our sample during 1995 - 2000. Different rates of return mainly affect the contribution of non-ICT capital since user cost of ICT capital is dominated by its price decline. In addition, we show that more than half of the ICT contribution results from growth in quality and change in composition rather than from growth in quantity. In this sense, MFP growth may tend to understate the overall effect of technological progress.

We do not conclude that the strong effect usually attributed to ICT and non-ICT investment in the UK and the US during 1995-2000 is necessarily the result of measurement error. But the results point to the fact that a sizeable part of the capital contribution can be attributed to returns to capital and ICT price declines that exceed our benchmark values, rather than to the quantity of investment alone. On the other hand, the qualityquantity decomposition reveals that the relative influence of ICT quantity is high if the overall ICT contribution is high. One reason is that increases in the capital stock are larger and pure replacement of depreciated capital plays a lesser role in this case.

This analysis could be extended in different directions. Instead of using a constant real rate of return to capital, one may consider more realistic measures of capital cost. Although some studies have already introduced such measures, the capacity of external rates of return to reflect differences in the marginal product across countries and over time has not been investigated in detail. Another extension of this work consists of introducing additional assumptions in order to identify the possible effects of non-constant returns to scale and mark-ups on MFP growth. The results on ICT contributions to growth, especially the large contribution of a change in ICT quality, underline the necessity to further develop quality-adjusted measurement and to better understand its implications for macroeconomic analysis. 


\section{A Appendix}

Table A.1: Contribution of ICT capital, non-ICT capital and MFP to labor productivity growth for different rates of return, period 1990-1995

\begin{tabular}{|c|c|c|c|c|c|c|c|c|}
\hline Country & Industry & LP & ICT $^{*}$ & $\mathrm{ICT}^{* *}$ & n.ICT* & n.ICT** & MFP* & $\mathrm{MFP}^{* *}$ \\
\hline \multirow[t]{4}{*}{$\mathrm{AT}$} & Market Economy & 2.84 & 0.39 & 0.36 & 0.51 & 0.45 & 1.29 & 1.35 \\
\hline & . Goods Production & 3.63 & 0.15 & 0.15 & 0.46 & 0.54 & 2.22 & 2.14 \\
\hline & Electrical Eqpt. & 5.04 & 0.24 & 0.22 & 0.82 & 0.65 & 3.73 & 3.91 \\
\hline & Market Services & 2.09 & 0.58 & 0.55 & 0.54 & 0.37 & 0.53 & 0.70 \\
\hline \multirow[t]{4}{*}{$\mathrm{AU}$} & Market Economy & 2.03 & 0.57 & 0.55 & 0.42 & 0.38 & 0.99 & 1.04 \\
\hline & Goods Production & 2.17 & 0.39 & 0.38 & 1.09 & 1.03 & 0.88 & 0.94 \\
\hline & .. Electrical Eqpt. & 8.74 & 0.76 & 0.72 & 1.60 & 1.20 & 6.32 & 6.75 \\
\hline & Market Services & 2.07 & 0.71 & 0.70 & -0.12 & -0.14 & 1.07 & 1.11 \\
\hline \multirow[t]{4}{*}{$\mathrm{DE}$} & Market Economy & 2.19 & . & $\cdot$ & . & . & $\cdot$ & \\
\hline & Goods Production & 2.25 & & & . & & $\cdot$ & \\
\hline & .. Electrical Eqpt. & 3.17 & . & & . & & . & \\
\hline & Market Services & 2.08 & & & & & & \\
\hline \multirow[t]{4}{*}{ ES } & Market Economy & 2.32 & 0.25 & 0.22 & 1.49 & 0.85 & -0.10 & 0.50 \\
\hline & . Goods Production & 3.56 & 0.12 & 0.12 & 1.47 & 0.88 & 1.00 & 1.55 \\
\hline & .. Electrical Eqpt. & 6.20 & 0.63 & 0.59 & 1.80 & 1.23 & 3.04 & 3.61 \\
\hline & Market Services & 1.15 & 0.38 & 0.32 & 1.48 & 0.81 & -1.20 & -0.57 \\
\hline \multirow[t]{4}{*}{ IT } & Market Economy & 2.69 & 0.20 & 0.20 & 0.76 & 0.75 & 1.55 & 1.56 \\
\hline & Goods Production & 3.34 & 0.11 & 0.11 & 1.00 & 1.13 & 1.97 & 1.84 \\
\hline & .. Electrical Eqpt. & 3.97 & 0.31 & 0.29 & 1.02 & 0.81 & 2.57 & 2.80 \\
\hline & Market Services & 2.07 & 0.28 & 0.28 & 0.55 & 0.41 & 1.17 & 1.30 \\
\hline \multirow[t]{4}{*}{ UK } & Market Economy & 3.47 & 0.58 & 0.53 & 1.23 & 1.23 & 1.64 & 1.68 \\
\hline & . Goods Production & 4.60 & 0.38 & 0.37 & 2.10 & 2.08 & 2.30 & 2.30 \\
\hline & Electrical Eqpt. & 7.10 & 0.89 & 0.80 & 0.90 & 0.74 & 4.46 & 4.64 \\
\hline & Market Services & 2.84 & 0.74 & 0.65 & 0.50 & 0.52 & 1.06 & 1.13 \\
\hline \multirow[t]{4}{*}{ US } & Market Economy & 1.88 & 0.68 & 0.60 & 0.47 & 0.31 & 0.63 & 0.82 \\
\hline & . Goods Production & 2.82 & 0.50 & 0.47 & 0.65 & 0.51 & 1.59 & 1.71 \\
\hline & .. Electrical Eqpt. & 12.89 & 1.04 & 0.94 & 1.21 & 0.75 & 10.11 & 10.61 \\
\hline & . Market Services & 1.39 & 0.81 & 0.68 & 0.34 & 0.19 & -0.00 & 0.23 \\
\hline
\end{tabular}

Notes: *internal rate of return $* * 4 \%+$ moving average CPI growth rate.

Source: EU KLEMS, November 2009 release. Own calculations.

Table A.2: Contribution of ICT capital, non-ICT capital and MFP to labor productivity growth for different rates of return, period 1995-2000

\begin{tabular}{|c|c|c|c|c|c|c|c|c|}
\hline Country & Industry & $\mathbf{L P}$ & ICT $^{*}$ & $\mathrm{ICT}^{* *}$ & n.ICT* & n.ICT ${ }^{* *}$ & MFP* & $\mathrm{MFP}^{* *}$ \\
\hline \multirow[t]{4}{*}{ AT } & Market Economy & 2.89 & 0.66 & 0.63 & 0.28 & 0.18 & 1.76 & 1.85 \\
\hline & . Goods Production & 5.47 & 0.40 & 0.39 & 0.63 & 0.43 & 4.13 & 4.30 \\
\hline & .. Electrical Eqpt. & 6.16 & 0.55 & 0.48 & 0.85 & 0.45 & 4.38 & 4.79 \\
\hline & . Market Services & 0.89 & 0.87 & 0.82 & -0.01 & -0.02 & -0.15 & -0.13 \\
\hline \multirow[t]{4}{*}{$\mathrm{AU}$} & Market Economy & 2.52 & 0.93 & 0.92 & 0.48 & 0.45 & 1.21 & 1.23 \\
\hline & . Goods Production & 2.06 & 0.70 & 0.70 & 0.91 & 0.80 & 0.75 & 0.82 \\
\hline & .. Electrical Eqpt. & -1.16 & 0.84 & 0.83 & -0.07 & -0.05 & -1.95 & -2.01 \\
\hline & . Market Services & 2.96 & 1.09 & 1.08 & 0.17 & 0.18 & 1.54 & 1.52 \\
\hline \multirow[t]{4}{*}{$\mathrm{DE}$} & Market Economy & 1.89 & 0.59 & 0.54 & 0.56 & 0.49 & 0.65 & 0.77 \\
\hline & . Goods Production & 2.86 & 0.22 & 0.22 & 0.64 & 0.63 & 1.79 & 1.79 \\
\hline & .. Electrical Eqpt. & 5.80 & 0.32 & 0.32 & 0.37 & 0.42 & 5.04 & 4.99 \\
\hline & . Market Services & 1.08 & 0.89 & 0.81 & 0.50 & 0.37 & -0.30 & -0.09 \\
\hline \multirow[t]{4}{*}{$\mathrm{ES}$} & Market Economy & 0.23 & 0.49 & 0.46 & 0.45 & 0.39 & -0.83 & -0.80 \\
\hline & Goods Production & -0.23 & 0.25 & 0.24 & 0.21 & 0.25 & -0.56 & -0.63 \\
\hline & .. Electrical Eqpt. & -0.64 & 1.19 & 1.15 & 0.19 & 0.16 & -2.34 & -2.30 \\
\hline & . Market Services & 0.62 & 0.72 & 0.66 & 0.68 & 0.51 & -1.10 & -0.96 \\
\hline \multirow[t]{4}{*}{ IT } & Market Economy & 1.16 & 0.41 & 0.38 & 0.39 & 0.10 & -0.04 & 0.26 \\
\hline & . Goods Production & 1.21 & 0.28 & 0.28 & 0.91 & 0.86 & -0.28 & -0.23 \\
\hline & .. Electrical Eqpt. & 1.00 & 0.77 & 0.75 & 0.70 & 0.58 & -0.57 & -0.43 \\
\hline & . Market Services & 1.10 & 0.52 & 0.47 & -0.04 & -0.51 & 0.15 & 0.66 \\
\hline \multirow[t]{4}{*}{ UK } & Market Economy & 2.78 & 1.15 & 1.03 & 0.62 & 0.38 & 0.61 & 0.91 \\
\hline & . Goods Production & 1.72 & 0.53 & 0.50 & 0.51 & 0.30 & 0.10 & 0.26 \\
\hline & .. Electrical Eqpt. & 6.29 & 1.20 & 1.02 & 0.48 & 0.24 & 3.89 & 4.16 \\
\hline & . Market Services & 3.72 & 1.58 & 1.41 & 0.72 & 0.45 & 1.01 & 1.40 \\
\hline \multirow[t]{4}{*}{ US } & Market Economy & 2.97 & 1.37 & 1.25 & 0.53 & 0.35 & 1.04 & 1.30 \\
\hline & Goods Production & 2.63 & 0.78 & 0.75 & 0.58 & 0.40 & 1.51 & 1.67 \\
\hline & .. Electrical Eqpt. & 18.46 & 1.30 & 1.20 & 1.01 & 0.65 & 15.72 & 16.13 \\
\hline & . Market Services & 3.25 & 1.73 & 1.55 & 0.49 & 0.31 & 0.76 & 1.07 \\
\hline
\end{tabular}

Notes: *internal rate of return $* * 4 \%+$ moving average CPI growth rate.

Source: EU KLEMS, November 2009 release. Own calculations. 
Table A.3: Contribution of ICT capital, non-ICT capital and MFP to labor productivity growth for different rates of return, period 2000-2007

\begin{tabular}{|c|c|c|c|c|c|c|c|c|}
\hline Country & Industry & $\mathbf{L P}$ & ICT $^{*}$ & $\mathrm{ICT}^{* *}$ & n.ICT* & n.ICT ${ }^{* *}$ & $\mathrm{MFP}^{*}$ & $\mathrm{MFP}^{* *}$ \\
\hline \multirow[t]{4}{*}{$\mathrm{AT}$} & Market Economy & 1.65 & 0.39 & 0.37 & -0.02 & 0.08 & 1.27 & 1.18 \\
\hline & . Goods Production & 3.53 & 0.21 & 0.21 & -0.04 & 0.02 & 2.88 & 2.82 \\
\hline & .. Electrical Eqpt. & 1.83 & 0.27 & 0.24 & -0.02 & -0.10 & 1.45 & 1.54 \\
\hline & . Market Services & 0.40 & 0.52 & 0.50 & -0.00 & 0.13 & 0.04 & -0.06 \\
\hline \multirow[t]{4}{*}{$\mathrm{AU}$} & Market Economy & 1.48 & 0.93 & 0.90 & 0.37 & 0.37 & -0.39 & -0.39 \\
\hline & . Goods Production & 1.50 & 0.67 & 0.67 & 0.52 & 0.36 & -0.85 & -0.73 \\
\hline & .. Electrical Eqpt. & 2.88 & 0.81 & 0.80 & 0.06 & 0.06 & 2.01 & 2.00 \\
\hline & . Market Services & 1.52 & 1.12 & 1.06 & 0.26 & 0.38 & -0.05 & -0.15 \\
\hline \multirow[t]{4}{*}{$\mathrm{DE}$} & Market Economy & 1.58 & 0.36 & 0.34 & 0.27 & 0.25 & 0.70 & 0.73 \\
\hline & . Goods Production & 2.79 & 0.16 & 0.16 & 0.30 & 0.31 & 1.84 & 1.83 \\
\hline & .. Electrical Eqpt. & 6.10 & 0.19 & 0.19 & 0.32 & 0.32 & 5.27 & 5.29 \\
\hline & . Market Services & 0.76 & 0.51 & 0.48 & 0.25 & 0.21 & -0.17 & -0.10 \\
\hline \multirow[t]{4}{*}{ ES } & Market Economy & 0.96 & 0.33 & 0.29 & 0.75 & 0.55 & -0.62 & -0.46 \\
\hline & . Goods Production & 0.93 & 0.18 & 0.17 & 0.79 & 0.56 & -0.59 & -0.45 \\
\hline & .. Electrical Eqpt. & 3.32 & 0.03 & 0.02 & 1.09 & 0.81 & 1.25 & 1.50 \\
\hline & . Market Services & 0.95 & 0.45 & 0.38 & 0.71 & 0.54 & -0.65 & -0.48 \\
\hline \multirow[t]{4}{*}{ IT } & Market Economy & 0.01 & 0.13 & 0.11 & 0.44 & 0.29 & -0.73 & -0.56 \\
\hline & . Goods Production & 0.10 & 0.08 & 0.08 & 0.55 & 0.54 & -0.65 & -0.64 \\
\hline & .. Electrical Eqpt. & -0.08 & 0.15 & 0.14 & 0.48 & 0.41 & -0.93 & -0.85 \\
\hline & . Market Services & -0.07 & 0.16 & 0.14 & 0.36 & 0.11 & -0.78 & -0.50 \\
\hline \multirow[t]{4}{*}{ UK } & Market Economy & 2.52 & 0.51 & 0.46 & 0.35 & 0.29 & 1.39 & 1.46 \\
\hline & . Goods Production & 2.59 & 0.29 & 0.27 & 0.65 & 0.39 & 1.46 & 1.73 \\
\hline & .. Electrical Eqpt. & 6.27 & 0.54 & 0.51 & 0.22 & 0.22 & 5.03 & 5.05 \\
\hline & . Market Services & 2.64 & 0.63 & 0.56 & 0.18 & 0.23 & 1.35 & 1.31 \\
\hline \multirow[t]{4}{*}{ US } & Market Economy & 2.45 & 0.59 & 0.55 & 0.38 & 0.28 & 1.38 & 1.49 \\
\hline & . Goods Production & 2.27 & 0.40 & 0.41 & 0.69 & 0.52 & 1.06 & 1.20 \\
\hline & .. Electrical Eqpt. & 13.49 & 0.41 & 0.42 & 0.49 & 0.69 & 11.72 & 11.57 \\
\hline & . Market Services & 2.68 & 0.69 & 0.62 & 0.22 & 0.15 & 1.56 & 1.64 \\
\hline
\end{tabular}

Notes: *internal rate of return $* * 4 \%+$ moving average CPI growth rate.

Source: EU KLEMS, November 2009 release. Own calculations. 


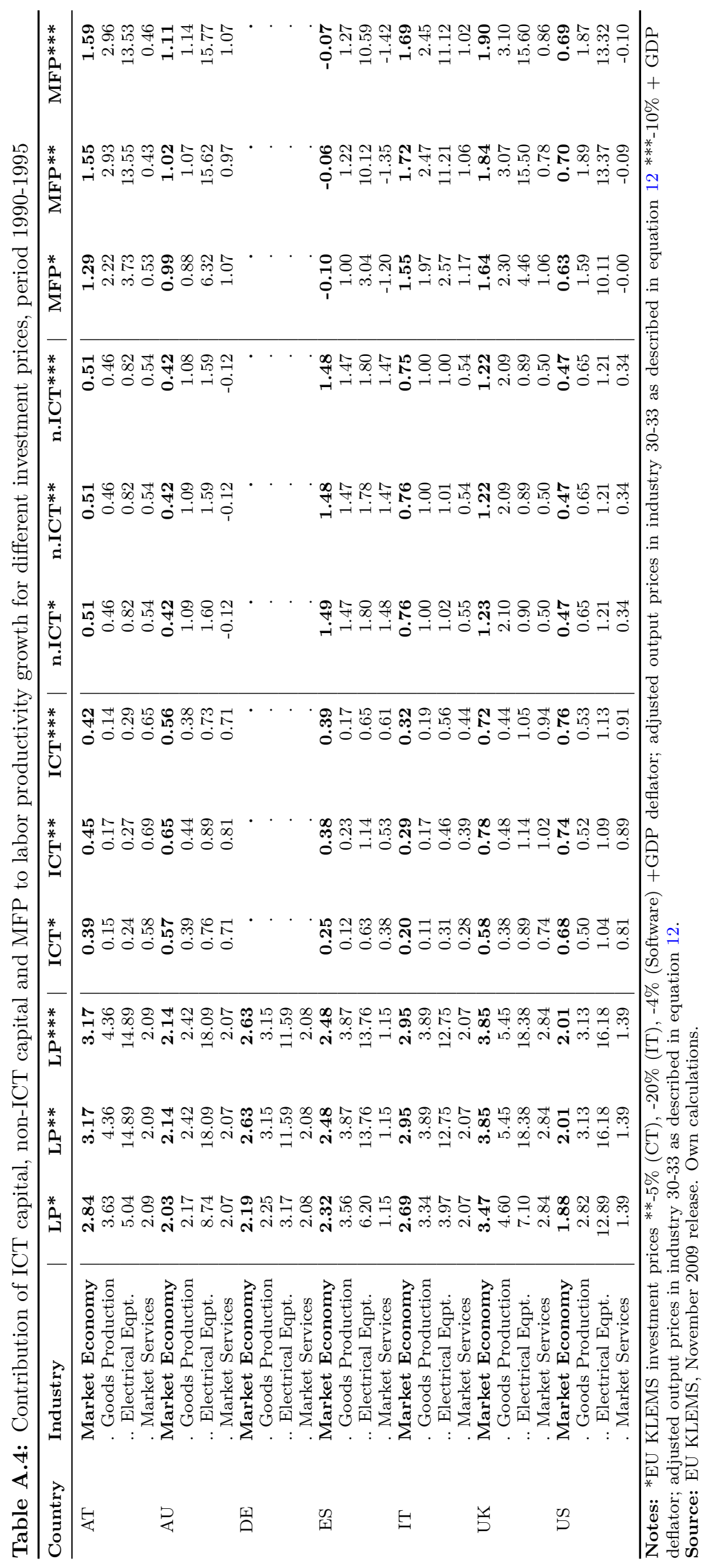




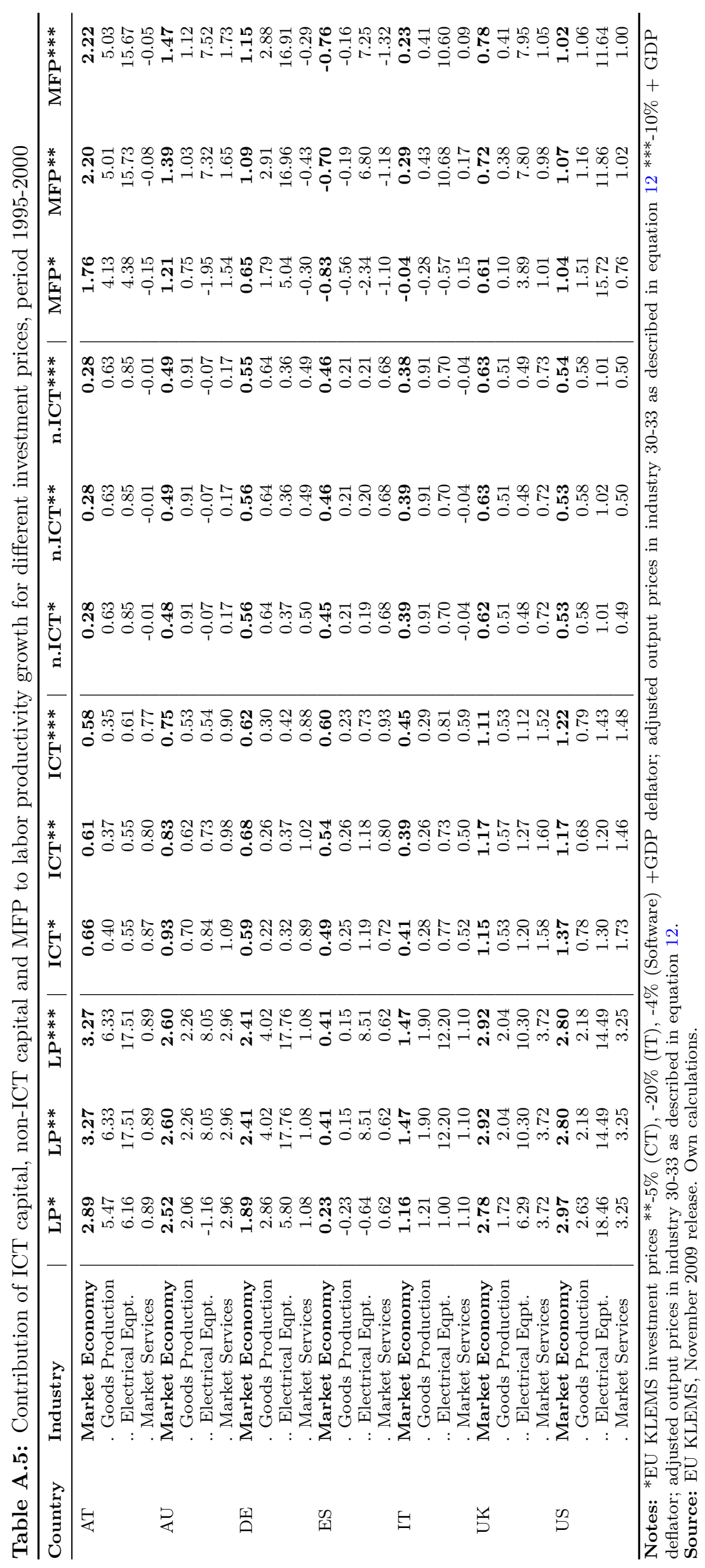




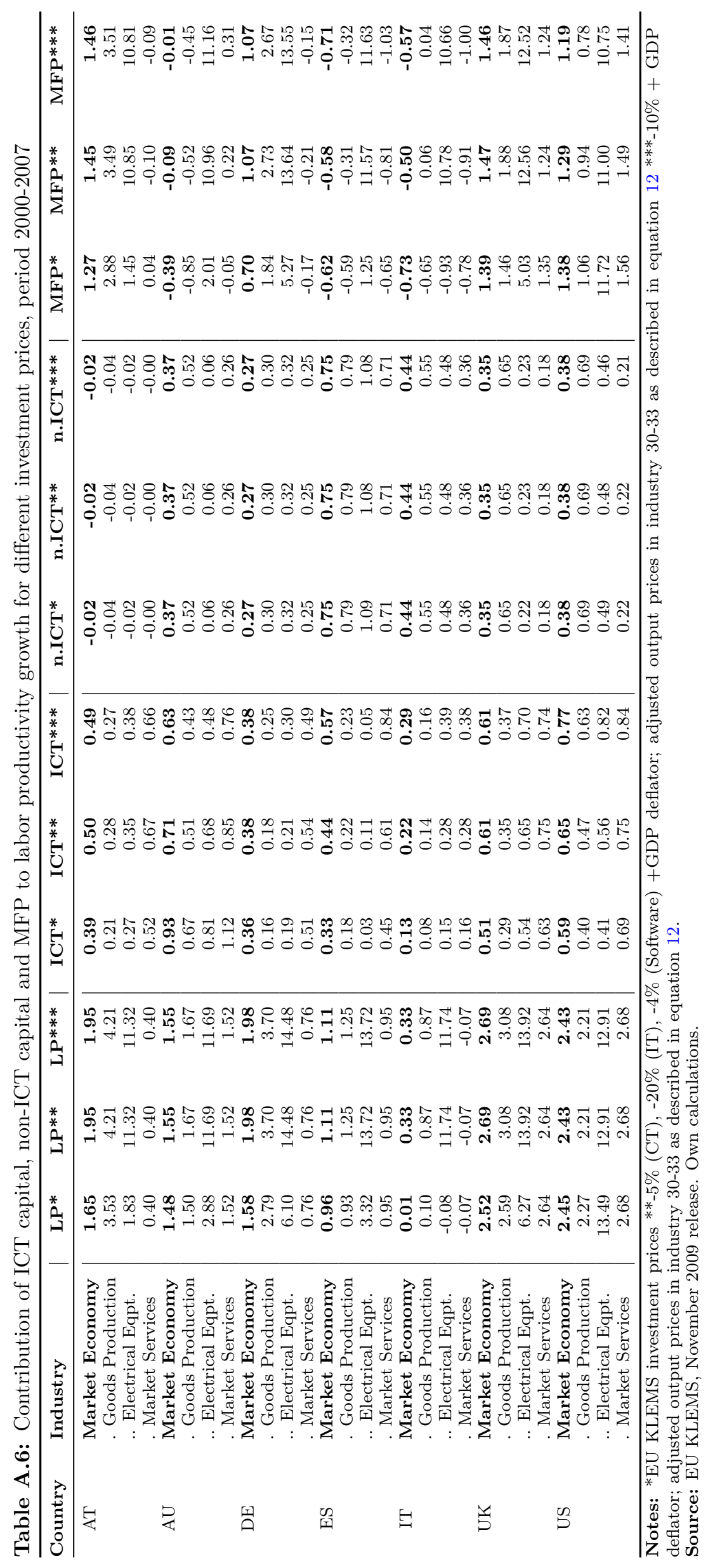




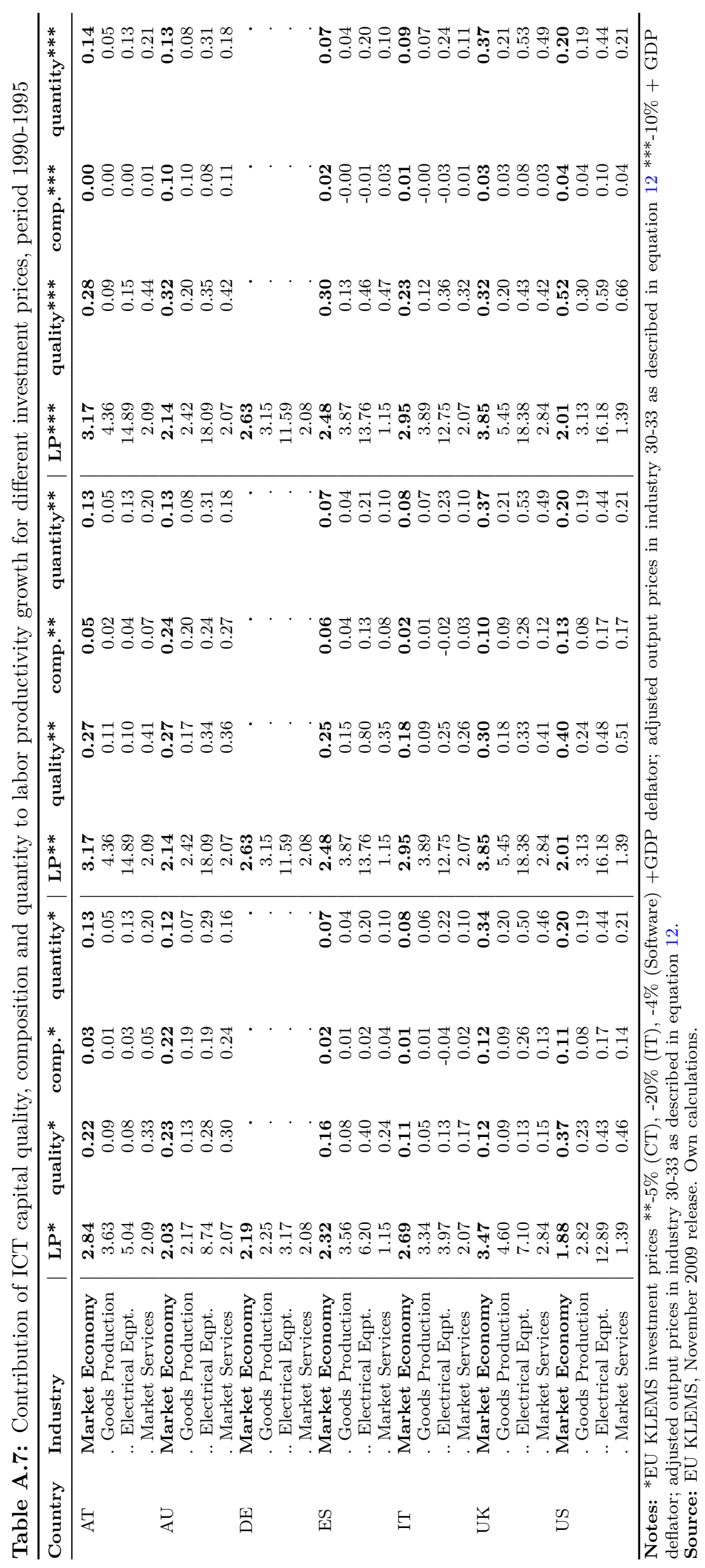




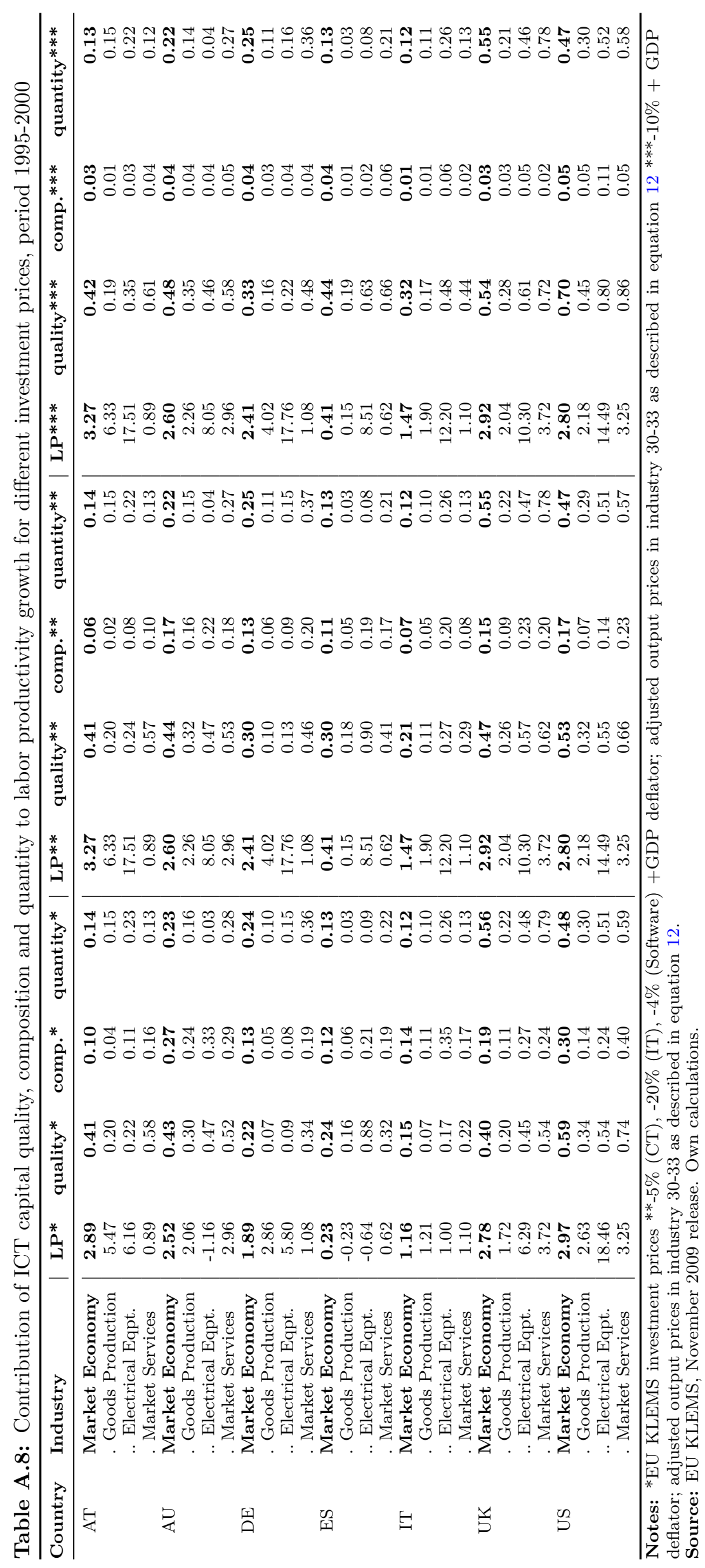




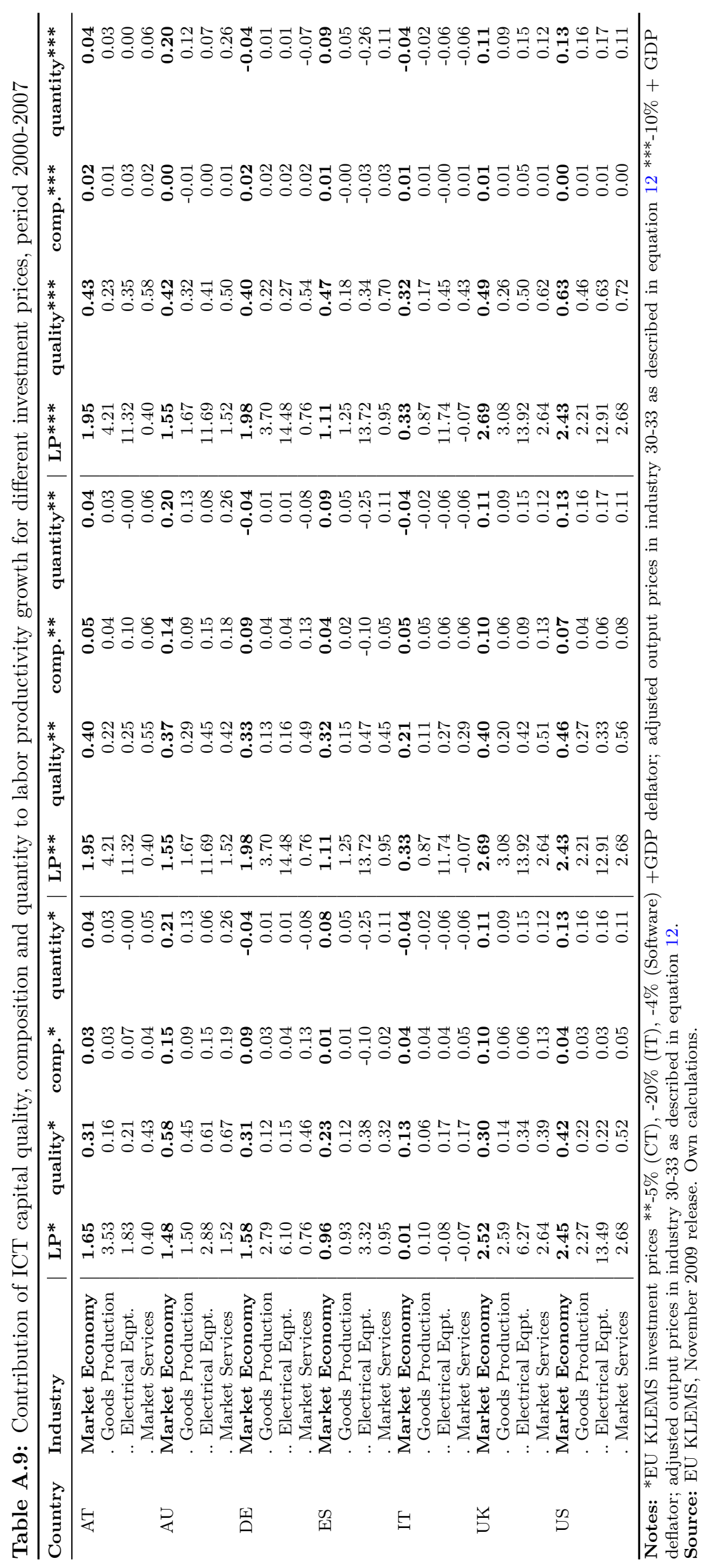


Table A.10: Sectoral contribution to market economy labor productivity growth for different investment prices, period 1990-1995

\begin{tabular}{|c|c|c|c|}
\hline Country & Industry & LP* & $\mathbf{L P} * *$ \\
\hline \multirow[t]{4}{*}{$\mathrm{AT}$} & Market Economy & 2.84 & 3.17 \\
\hline & . Goods Production & 1.64 & 1.98 \\
\hline & .. Electrical Eqpt. & 0.17 & 0.50 \\
\hline & . Market Services & 1.14 & 1.14 \\
\hline \multirow{4}{*}{$\mathrm{AU}$} & Market Economy & 2.03 & 2.14 \\
\hline & . Goods Production & 0.98 & 1.09 \\
\hline & .. Electrical Eqpt. & 0.10 & 0.21 \\
\hline & . Market Services & 1.15 & 1.15 \\
\hline \multirow[t]{4}{*}{$\mathrm{DE}$} & Market Economy & 2.19 & 2.63 \\
\hline & . Goods Production & 1.10 & 1.54 \\
\hline & .. Electrical Eqpt. & 0.19 & 0.63 \\
\hline & . Market Services & 1.04 & 1.04 \\
\hline \multirow[t]{4}{*}{$\mathrm{ES}$} & Market Economy & 2.32 & 2.48 \\
\hline & . Goods Production & 1.80 & 1.96 \\
\hline & .. Electrical Eqpt. & 0.13 & 0.28 \\
\hline & . Market Services & 0.58 & 0.58 \\
\hline \multirow[t]{4}{*}{ IT } & Market Economy & 2.69 & 2.95 \\
\hline & . Goods Production & 1.55 & 1.81 \\
\hline & .. Electrical Eqpt. & 0.11 & 0.37 \\
\hline & . Market Services & 1.12 & 1.12 \\
\hline \multirow[t]{4}{*}{ UK } & Market Economy & 3.47 & 3.85 \\
\hline & . Goods Production & 2.11 & 2.49 \\
\hline & .. Electrical Eqpt. & 0.24 & 0.62 \\
\hline & . Market Services & 1.57 & 1.57 \\
\hline \multirow[t]{4}{*}{ US } & Market Economy & 1.88 & 2.01 \\
\hline & . Goods Production & 1.13 & 1.26 \\
\hline & .. Electrical Eqpt. & 0.52 & 0.65 \\
\hline & . Market Services & 0.83 & 0.83 \\
\hline
\end{tabular}

Notes: *EU KLEMS **adjusted output prices in industry 30-33 as described in equation 12 . Sectoral contributions do not sum up to market economy due to reallocation of labor. Electrical equipment is a sub-sector of goods production. Source: EU KLEMS, November 2009 release. Own calculations.

Table A.11: Sectoral contribution to market economy labor productivity growth for different investment prices, period 1995-2000

\begin{tabular}{|c|c|c|c|}
\hline Country & Industry & $\mathbf{L P} *$ & $\mathbf{L P} * *$ \\
\hline \multirow[t]{4}{*}{$\mathrm{AT}$} & Market Economy & 2.89 & 3.27 \\
\hline & . Goods Production & 2.45 & 2.83 \\
\hline & .. Electrical Eqpt. & 0.21 & 0.59 \\
\hline & . Market Services & 0.49 & 0.49 \\
\hline \multirow[t]{4}{*}{$\mathrm{AU}$} & Market Economy & 2.52 & 2.60 \\
\hline & . Goods Production & 0.88 & 0.97 \\
\hline & .. Electrical Eqpt. & 0.00 & 0.09 \\
\hline & . Market Services & 1.70 & 1.70 \\
\hline \multirow[t]{4}{*}{$\mathrm{DE}$} & Market Economy & 1.89 & 2.41 \\
\hline & . Goods Production & 1.30 & 1.83 \\
\hline & .. Electrical Eqpt. & 0.27 & 0.80 \\
\hline & . Market Services & 0.59 & 0.59 \\
\hline \multirow[t]{4}{*}{$\mathrm{ES}$} & Market Economy & 0.23 & 0.41 \\
\hline & . Goods Production & -0.11 & 0.07 \\
\hline & .. Electrical Eqpt. & -0.01 & 0.17 \\
\hline & . Market Services & 0.34 & 0.34 \\
\hline \multirow[t]{4}{*}{ IT } & Market Economy & 1.16 & 1.47 \\
\hline & . Goods Production & 0.53 & 0.84 \\
\hline & .. Electrical Eqpt. & 0.03 & 0.34 \\
\hline & . Market Services & 0.62 & 0.62 \\
\hline \multirow[t]{4}{*}{ UK } & Market Economy & 2.78 & 2.92 \\
\hline & . Goods Production & 0.71 & 0.85 \\
\hline & .. Electrical Eqpt. & 0.22 & 0.36 \\
\hline & . Market Services & 2.18 & 2.18 \\
\hline \multirow[t]{4}{*}{ US } & Market Economy & 2.97 & 2.80 \\
\hline & . Goods Production & 1.00 & 0.83 \\
\hline & .. Electrical Eqpt. & 0.76 & 0.60 \\
\hline & . Market Services & 2.02 & 2.02 \\
\hline
\end{tabular}

Notes: *EU KLEMS **adjusted output prices in industry 30-33 as described in equation 12 . Sectoral contributions do not sum up to market economy due to reallocation of labor. Electrical equipment is a sub-sector of goods production.

Source: EU KLEMS, November 2009 release. Own calculations. 
Table A.12: Sectoral contribution to market economy labor productivity growth for different investment prices, period 2000-2007

\begin{tabular}{|c|c|c|c|}
\hline Country & Industry & $\mathbf{L P}^{*}$ & $\mathbf{L P} * *$ \\
\hline \multirow[t]{4}{*}{$\mathrm{AT}$} & Market Economy & 1.65 & 1.95 \\
\hline & Goods Production & 1.52 & 1.82 \\
\hline & .. Electrical Eqpt. & 0.06 & 0.36 \\
\hline & . Market Services & 0.23 & 0.23 \\
\hline \multirow[t]{4}{*}{$\mathrm{AU}$} & Market Economy & 1.48 & 1.55 \\
\hline & . Goods Production & 0.63 & 0.70 \\
\hline & .. Electrical Eqpt. & 0.03 & 0.10 \\
\hline & . Market Services & 0.89 & 0.89 \\
\hline \multirow[t]{4}{*}{$\mathrm{DE}$} & Market Economy & 1.58 & 1.98 \\
\hline & . Goods Production & 1.21 & 1.61 \\
\hline & .. Electrical Eqpt. & 0.30 & 0.70 \\
\hline & . Market Services & 0.43 & 0.43 \\
\hline \multirow[t]{4}{*}{ ES } & Market Economy & 0.96 & 1.11 \\
\hline & . Goods Production & 0.41 & 0.55 \\
\hline & .. Electrical Eqpt. & 0.05 & 0.19 \\
\hline & . Market Services & 0.53 & 0.53 \\
\hline \multirow[t]{4}{*}{ IT } & Market Economy & 0.01 & 0.33 \\
\hline & . Goods Production & 0.04 & 0.36 \\
\hline & .. Electrical Eqpt. & -0.00 & 0.32 \\
\hline & . Market Services & -0.04 & -0.04 \\
\hline \multirow[t]{4}{*}{ UK } & Market Economy & 2.52 & 2.69 \\
\hline & . Goods Production & 0.91 & 1.08 \\
\hline & .. Electrical Eqpt. & 0.13 & 0.30 \\
\hline & . Market Services & 1.73 & 1.73 \\
\hline \multirow[t]{4}{*}{ US } & Market Economy & 2.45 & 2.43 \\
\hline & . Goods Production & 0.80 & 0.78 \\
\hline & .. Electrical Eqpt. & 0.40 & 0.38 \\
\hline & . Market Services & 1.73 & 1.73 \\
\hline
\end{tabular}

Notes: *EU KLEMS **adjusted output prices in industry $30-33$ as described in equation 12 . Sectoral contributions do not sum up to market economy due to reallocation of labor. Electrical equipment is a sub-sector of goods production.

Source: EU KLEMS, November 2009 release. Own calculations.

Table A.13: Industry Classification

\begin{tabular}{lr}
\hline Industry & NACE revision $\mathbf{1 . 1}$ \\
\hline Market Economy & $1-67,71-74,90-93$ \\
. Goods Production & $1-45$ \\
.. Electrical Equipment & $30-33$ \\
. Market Services & $50-67,71-74,90-93$ \\
.. Trade & $50-52$ \\
.. Hotels and Restaurants & 55 \\
.. Transport and Storage & $60-63$ \\
. Post and Telecommunications & 64 \\
. Financial Intermediates & $65-67$ \\
.. Business Services & $71-74$ \\
.. Other Services & $90-93$ \\
\hline
\end{tabular}


Figure A.1: Different methods of measuring rates of return - MARKET ECONOMY Nominal rate of return 1990-1995
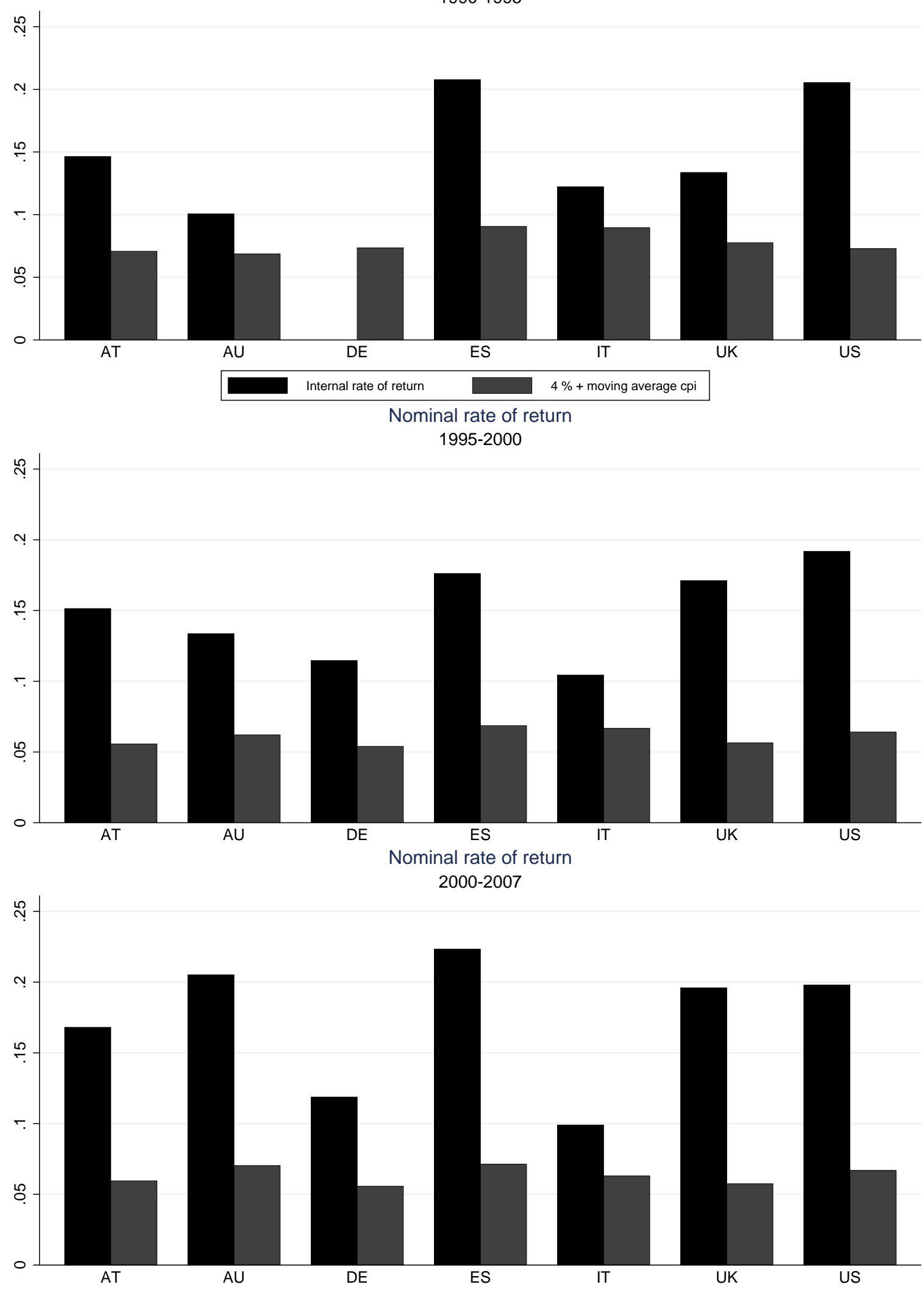

Source: EU KLEMS, November 2009 release. Own calculations. 
Figure A.2: Different methods of measuring ICT price changes - MARKET ECONOMY

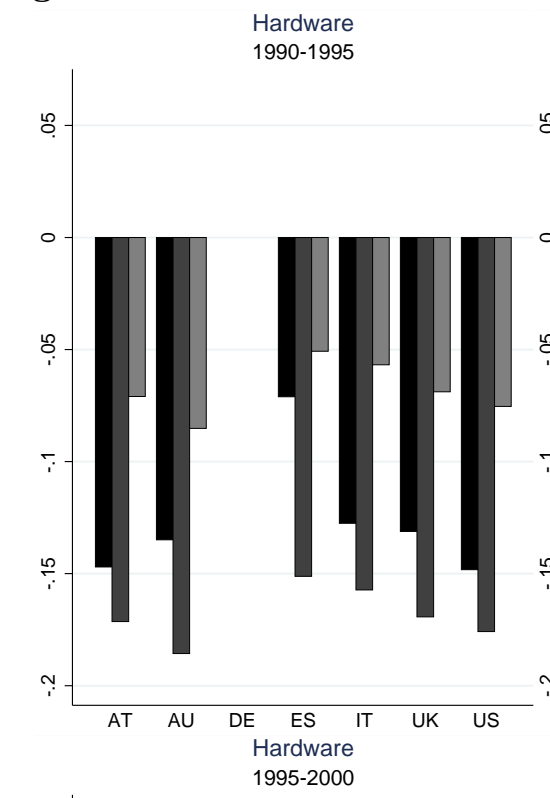
Communications eq.

Software

Hardware 1990-1995

1990-1995
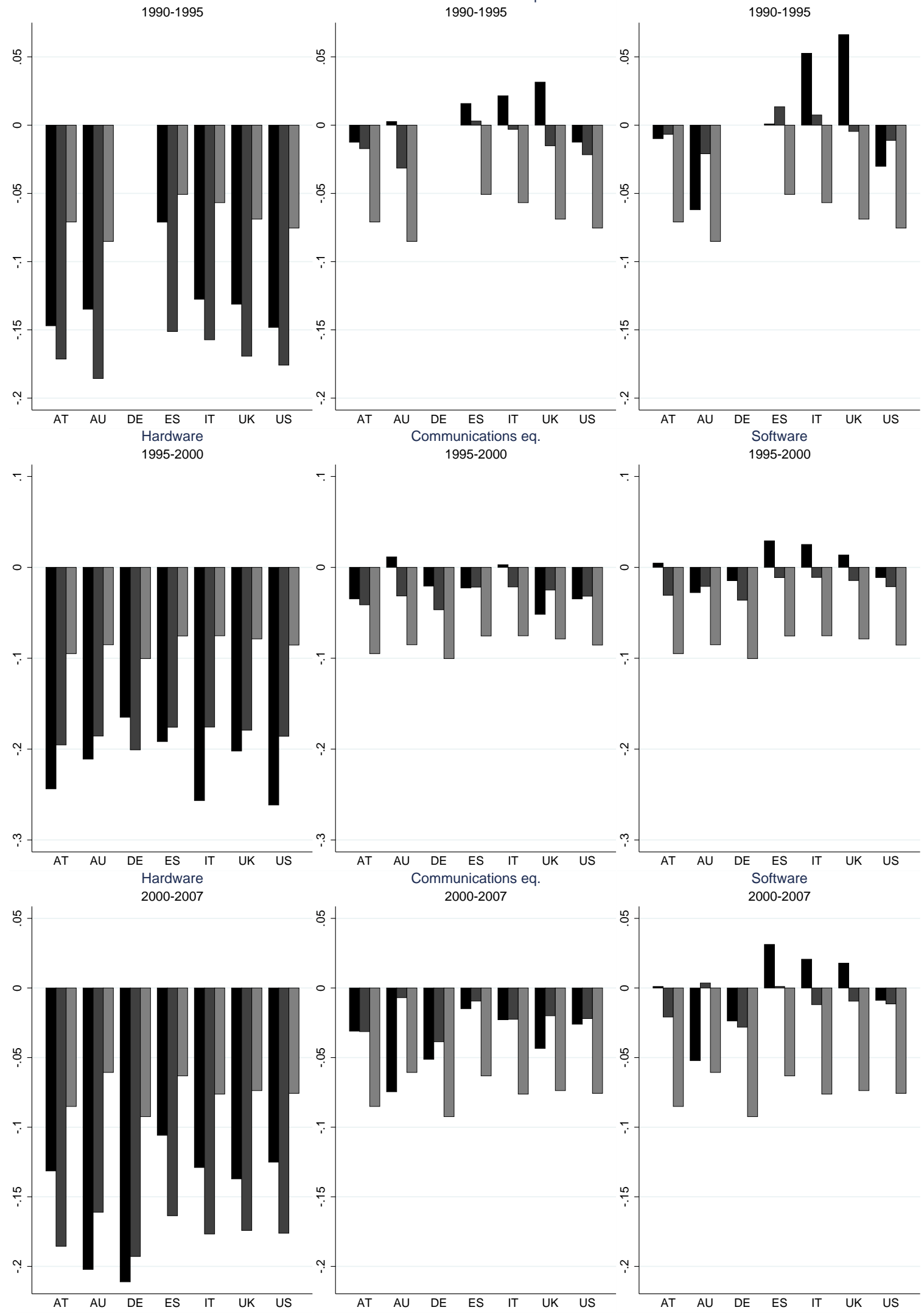

Notes: Bar(1): EU KLEMS investment prices Bar(2): -5\% (CT), -20\% (IT), -4\% (Software) +GDP deflator Bar(3): -10\% + GDP deflator.

Source: EU KLEMS, November 2009 release. Own calculations. 


\section{References}

Bassanini, A. and Scarpetta, S. (2002), 'Growth, Technological Change, and ICT Diffusion: Recent Evidence from OECD Countries', Oxford Review of Economic Policy 18(3), 324-344.

Colecchia, A. and Schreyer, P. (2002), 'ICT Investment and Economic Growth in the 1990s: Is the United States a Unique Case?: A Comparative Study of Nine OECD Countries', Review of Economic Dynamics 5(2), 408-442.

Cummins, J. G. and Violante, G. L. (2002), 'Investment-Specific Technical Change in the United States (1947-2000): Measurement and Macroeconomic Consequences', Review of Economic Dynamics 5(2), 243-284.

Diewert, W. (2001), 'Measuring the Price and Quantity of Capital Services under Alternative Assumptions', Department of Economics, University of British Columbia, Discussion Paper (01-24).

Inklaar, R. (2010), 'The Sensitivity of Capital Services Measurement: Measure all Assets and the Cost of Capital', Review of Income and Wealth 56(2), 389-412.

Inklaar, R., O'Mahony, M. and Timmer, M. (2005), 'ICT and Europe's Productivity Performance: Industry-Level Growth Account Comparisons with the United States', Review of Income and Wealth 51(4), 505-536.

Jorgenson, D. (2001), 'Information Technology and the US Economy', American Economic Review 91(1), 1-32.

Jorgenson, D. (2005), Productivity, Vol. 3 Information Technology and the American Growth Resurgence, MIT Press.

OECD (2010), 'Main Economic Indicators - Complete Database', Main Economic Indicators (database).

O'Mahony, M. and Timmer, M. (2009), 'Output, Input and Productivity Measures at the Industry Level: The EU KLEMS Database', Economic Journal 119(538), F374-F403.

Oulton, N. (2007), 'Ex Post versus Ex Ante Measures of the User Cost of Capital', Review of Income and Wealth 53(2), 295-317.

Oulton, N. (2010), Long Term Implications of the ICT Revolution: Applying the Lessons of Growth Theory and Growth Accounting, CEP Discussion Papers dp1027, Centre for Economic Performance, LSE. 
Oulton, N. and Rincon-Aznar, A. (2010), 'Rates of Return and Alternative Measures of Capital Input: 14 Countries and 10 Branches, 1971-2005', Paper presented at the First World KLEMS Conference, Harvard University, 19-20 August 2010.

Schreyer, P. (2002), 'Computer Price Indices and International Growth and Productivity Comparisons', Review of Income and Wealth 48(1), 15-31.

Schreyer, P. (2010), Measuring Multi-Factor Productivity when Rates of Return are Exogenous, in W. E. Diewert, B. M. Balk, D. Fixler, K. J. Fox and A. O. Nakamura, eds, 'Price and Productivity Measurement: Volume 6 - Index Number Theory', Trafford Press, chapter 2, pp. 13-40.

Van Ark, B., O’Mahony, M. and Timmer, M. (2008), 'The Productivity Gap Between Europe and the United States: Trends and Causes', The Journal of Economic Perspectives 22(1), 25-44. 